\title{
Essay
}

\section{Bush v. Gore and the Boundary Between Law and Politics}

\author{
Jack M. Balkin ${ }^{\dagger}$
}

Shortly after the Supreme Court's 5-4 decision in Bush v. Gore, ${ }^{1}$ one member of the majority, Associate Justice Clarence Thomas, addressed a group of students in the Washington, D.C., area. He told them that he believed that the work of the Court was not in any way influenced by politics or partisan considerations. ${ }^{2}$ This speech was widely reported in the press. Afterwards the question on many legal scholars' minds was not whether Justice Thomas had in fact made these statements. The question was whether he also told the students that he believed in Santa Claus, the Easter Bunny, and the Tooth Fairy.

It is no secret that the Supreme Court's decision in Bush v. Gore has shaken the faith of many legal academics in the Supreme Court and in the system of judicial review. ${ }^{3}$ It is worth considering why this should be so.

$\dagger$ Knight Professor of Constitutional Law and the First Amendment, Yale Law School. My thanks to Bruce Ackerman, Akhil Amar, Michael Klarman, Sanford Levinson, Richard Posner, Jed Rubenfeld, Reva Siegel, and Mark Tushnet for their comments on previous drafts, and to Richard Daniel Albert for his research assistance.

1. 121 S. Ct. 525 (2000).

2. Thomas was quoted as saying, "I have yet to hear any discussion, in nine years, of partisan politics" among the Justices. "I plead with you that, whatever you do, don't try to apply the rules of the political world to this institution; they do not apply." In fact, he claimed that "[t]he last political act we engage in is confirmation." Linda Greenhouse, Another Kind of Bitter Split, N.Y. TIMES, Dec. 14, 2000, at A1. Shortly thereafter, Chief Justice William H. Rehnquist was asked by a reporter if he thought Justice Thomas's remarks about nonpartisanship were especially appropriate in light of the recent case. He replied, "Absolutely." Neil A. Lewis, Justice Thomas Speaks Out on a Timely Topic, Several of Them, in Fact, N.Y. TIMES, Dec. 14, 2000, at A23.

3. See, e.g., Ledyard King, Regular People, Weighty Decision Put High Court in New Light, GANNETT NEWS SERVICE, Dec. 14, 2000 (quoting Michael Gerhardt as stating that "the court has transformed itself into a political institution. . . . [I]t is going to be very difficult for anyone to look for any neutral principle to defend in this kind of outcome"); Jeffrey Rosen, Disgrace, NEW 
Legal academics rationalize bad judicial decisions all the time; that is part of their job description. Moreover, the fact that a few judges occasionally make mistakes in legal reasoning, even very egregious mistakes, should come as no surprise, nor should it cause one to lose faith in the rule of law, the U.S. Supreme Court, or in the system of judicial review. Likewise, the fact that a few judges occasionally decide cases because they secretly favor one party over another should also come as no surprise; nor should isolated examples of judicial corruption cause one to lose faith in a larger process of legal decisionmaking. The problem with Bush v. Gore, I suspect, was the case was too salient an example of judicial misbehavior for many legal academics to swallow. It was no isolated fender bender in which a local judge helped out the son of a former law partner. Rather, the case decided the outcome of a presidential election and may well have determined who would sit on the Supreme Court and the lower federal courts for decades to come. Moreover, unlike the judge deciding the case of a fender bender in some obscure venue, the Court could not have failed to recognize that all eyes were upon it. That the conservative Justices acted as they did suggested that their partisanship was so thorough and pervasive that it blinded them to their own biases. It seemed as if they had lost all sense of perspective.

In addition, Bush v. Gore was troubling because it suggested that the Court was motivated by a particular kind of partisanship, one much more narrow than the promotion of broad political principles through the development of constitutional doctrine. The distinction is between the "high" politics of political principle and the "low" politics of partisan advantage. ${ }^{4}$ The same five conservative Justices who formed the majority in Bush v. Gore had been engaged, for over a decade, in a veritable revolution in constitutional doctrines concerning civil rights and federalism. ${ }^{5}$ In those decisions, the five conservatives had been promoting a

REPUBLIC, Dec. 25, 2000, at 18 (arguing that the Court has "made it impossible for citizens of the United States to sustain any kind of faith in the rule of law as something larger than the selfinterested political preferences of Justices William Rehnquist, Antonin Scalia, Clarence Thomas, Anthony Kennedy, and Sandra Day O'Connor"); David G. Savage \& Henry Weinstein, Supreme Court Ruling: Right or Wrong, L.A. TIMES, Dec. 21, 2000, at A24 (quoting Akhil Reed Amar as stating that "[m]any of us thought that courts do not act in an openly political fashion. So this decision comes as a startling event that has shaken constitutional faith. . . . I have less respect for the court than before").

4. I am indebted to Sanford Levinson for this point, as for so much else over the years. See Sanford Levinson, Return of Legal Realism, NATION, Jan. 8, 2001, at 8.

5. E.g., Bd. of Trs. of the Univ. of Ala. v. Garrett, 121 S. Ct. 955 (2001); United States v. Morrison, 529 U.S. 598 (2000); Kimel v. Fla. Bd. of Regents, 528 U.S. 62 (2000); Alden v. Maine, 527 U.S. 706 (1999); Fla. Prepaid Postsecondary Educ. Expense Bd. v. Coll. Sav. Bank, 527 U.S. 627 (1999); Printz v. United States, 521 U.S. 898 (1997); Seminole Tribe v. Florida, 517 U.S. 44 (1996); United States v. Lopez, 514 U.S. 549 (1995); New York v. United States, 505 U.S. 144 (1992) (6-3 decision); Gregory v. Ashcroft, 501 U.S. 452 (1991). Since Justice Thomas replaced Justice Marshall in 1991, cementing a solid five-person conservative majority, the same five Justices have also created new doctrines in voting rights law, see, e.g., Miller v. Johnson, 515 
relatively consistent set of ideological positions like colorblindness, respect for state autonomy from federal interference, and protection of state governmental processes from federal supervision. But the decision in Bush v. Gore did not seem to further those values, at least not directly. Rather, the five conservatives seemed to adopt whatever legal arguments would further the election of the Republican candidate, George W. Bush. This is the "low" politics of partisan political advantage. Although few legal academics these days are shocked to learn that Justices' decisions are "political" in the sense that they promote "high politics"-larger political principles and ideological goals-they were quite disturbed by the possibility that Justices would use the power of judicial review in so prominent a case to promote the interests of a particular political party and install its candidates in power.

Indeed, the appearance, if not the reality, of this kind of partisanship in Bush v. Gore casts an unsavory light on the constitutional revolution of the last decade. It was widely speculated before and after the election that several of the Justices might retire within the next few years. By intervening in the election, the five conservatives installed a President who would appoint their colleagues and successors and would stock the federal judiciary with like-minded conservatives. Bush v. Gore was troubling because the five conservatives appeared to use the power of judicial review to secure control of another branch of government that would, in turn, help keep their constitutional revolution going. It is one thing to entrench one's constitutional principles through a series of precedents. It is quite another to entrench one's ideological allies by directing the outcome of a presidential election.

Because law professors are perhaps as committed to the legitimacy of the courts and the legal system as anyone else, Bush v. Gore will require them to reduce cognitive dissonance in manifold ways. Many of these forms of dissonance reduction have already begun. In this Essay, I discuss five features of the opinion. In Part I, I discuss the constitutional issues in Bush v. Gore and explain why so many people thought the Court's opinion was unpersuasive. In Part II, I consider the Court's institutional role and whether its choice to intervene in the election dispute was justified. Part III discusses the jurisprudential implications of Bush v. Gore-and in particular its relationship to two very well-known theories of jurisprudence, American Legal Realism and Critical Legal Studies. Part IV considers the place of Bush v. Gore in the "legal canon"-how the case will be understood, taught, and remembered. Finally, Part V offers a few

U.S. 900 (1995); Shaw v. Reno, 509 U.S. 630 (1993), and confirmed that race-based affirmative action will be strongly disfavored whether practiced by the federal government or by the states, see Adarand Constructors v. Pena, 515 U.S. 200 (1995). 
suggestions about what the case means for the Court's legitimacy, both in the short term and in the long run. It also argues that, because of important structural features of the American Constitution, party politics provides the best remedy for the Court's actions.

\section{THE LEgAL ARGUMENTS IN BUSH V. GORE}

The Supreme Court intervened in the 2000 election not once but three times. Only the last two of these interventions are called Bush v. Gore. The first opinion, Bush v. Palm Beach County Canvassing Board, ${ }^{6}$ followed the Florida Supreme Court's November 21 decision to extend the time for ballot certification past the date set by Florida statute. ${ }^{7}$ The Supreme Court granted certiorari, and heard the case on December 1 . Shortly after the oral argument began, the Court discovered that it had misplayed its hand. The Justices apparently thought that, by intervening in a dispute over certification, they could lend their enormous prestige to settling the nation's election crisis once and for all. By the time oral arguments began, however, they had discovered two embarrassing facts. First, the certification had already occurred. Nothing they could do in the case before them would change the outcome of the election contest that had begun in Florida after they granted an appeal. Second, they were badly divided along ideological lines, and any decision on the merits might undermine their own legitimacy. In important decisions like Brown v. Board of Education ${ }^{8}$ and the Nixon tapes case, United States v. Nixon, ${ }^{9}$ the Court has chosen to speak unanimously in order to enhance its authority and to avoid the appearance that such momentous decisions are motivated by partisan politics. ${ }^{10}$ So the Justices effectively punted, unanimously voting to send the case back to the Florida Supreme Court with instructions on how to rewrite its opinion to avoid creating a federal question.

6. 121 S. Ct. 471 (2000).

7. Palm Beach County Canvassing Bd. v. Harris, 772 So. 2d 1220 (Fla. 2000)

8. 347 U.S. 483 (1954).

9. 418 U.S. 683 (1974).

10. In United States v. Nixon, all the Justices joined in Chief Justice Burger's majority opinion except then-Justice Rehnquist, who had been a member of the Nixon Justice Department and therefore did not participate. In Brown v. Board of Education, Chief Justice Warren worked to avoid even a concurrence by Justices Jackson or Frankfurter. RICHARD KLUGER, SIMPLE JUSTICE: THE History OF BROWN V. BOARD OF EDUCATION AND BLACK AMERICA's STRUGGLE FOR EQUALITY 683 (1975); Jack M. Balkin, Brown v. Board of Education: A Critical Introduction, in WHAT BROWN V. BOARD OF EDUCATION SHOULD HAVE SAID: THE NATION'S TOP LEGAL EXPERTS REWRITE AMERICA'S LANDMARK CIVIL RIGHTS DECISION (Jack M. Balkin ed., forthcoming 2001) (manuscript at 35-41, on file with author) [hereinafter WHAT BROWN]; Dennis J. Hutchinson, Unanimity and Desegregation: Decisionmaking in the Supreme Court, 1948-1958, 68 GEO. L.J. 1, 56 (1979). 
Then on Friday, December 8, the Florida Supreme Court ordered a statewide recount of ballots. ${ }^{11}$ But instead of the unanimous ruling it had offered a few weeks before, it split 4-3. The next day, the U.S. Supreme Court took the case a second time, again using its discretionary power of certiorari. It granted a temporary stay of all recounts in Florida. ${ }^{12}$ The December 9 per curiam order in Bush v. Gore was accompanied by two opinions: one by Justice Scalia arguing in support of the stay, and one written by Justice Stevens and joined by the other three liberal Justices dissenting from the stay. Grounds for granting such a stay require both probable success on the merits and a showing of irreparable harm if the stay is not granted. Granting the stay showed that the five most conservative Justices were inclined to rule in Bush's favor without further argument. But how could Bush have been irreparably harmed by letting the recounts continue? One would think that the irreparable harm would be to Gore, who would not be able to get a recount finished in time. (Remember that at the point the stay went into effect, Gore was less than two hundred votes behind and there was every possibility that if the recount had continued for several more hours Gore would have pushed ahead.) ${ }^{13}$ Justice Scalia's opinion argued that " $[\mathrm{t}]$ he counting of votes that are of questionable legality does in my view threaten irreparable harm to petitioner [George W. Bush], and to the country, by casting a cloud upon what he claims to be the legitimacy of his election." "14 Put another way, the threat to the legitimacy of Bush's presidency was real and palpable, while the harm to Gore's chances of proving that he had actually won more votes in Florida was less important. This view makes perfect sense if the Court had already made up its mind that Bush would win the case and become president. ${ }^{15}$ By now the

11. Gore v. Harris, 772 So. 2d 1243 (Fla. 2000). More correctly, the court ordered a statewide recount of so-called undervotes, in which machine counts had not detected any choice for President. The court did not order a recount of so-called overvotes, in which a vote for two or more candidates had been detected by the machines. There is some evidence that including overvotes would actually have benefited Gore. David Damron et al., Gore Would Have Gained Votes in GOP Stronghold: Overvotes Counted Elsewhere, ORLANDO SENTINEL, Dec. 19, 2000, at A1; Joel Engelhardt \& Scott McCabe, Election 2000: Over-Votes Cost Gore the Election in FL, PALM BeACH Post, Mar. 10, 2001, at 1A.

12. Bush v. Gore (Bush I), 121 S. Ct. 512 (2000).

13. See, e.g., Charles M. Madigan \& James Warren, U.S. High Court Halts Recount, CHI. TRIB., Dec. 10, 2000, at C1 (noting that at the time the stay was granted Bush's lead was reduced to 154 votes and that Gore might also have picked up an additional 58 votes); Kevin Sack, At Center Stage: Appellate Judges Permit Recounts, Then U.S. Justices Steal the Show, N.Y. TIMES, Dec. 10, 2000, at A1 (stating that Bush was ahead by only 154 votes). Bush's lawyers argued that the figure was closer to 193. Michael Kranish \& Johan Aloysius Farrell, On Again, Off Again U.S. Supreme Court Halts Florida's Manual Recounts, PlaIn DEALER, Dec. 10, 2000, at A1.

14. 121 S. Ct. at 512 (Scalia, J., concurring).

15. Scalia's other argument for the stay was that "permitting the count to proceed on that erroneous basis will prevent an accurate recount from being conducted on a proper basis later, since it is generally agreed that each manual recount produces a degradation of the ballots, which renders a subsequent recount inaccurate." Id. There are two problems with this argument. First, it is not generally agreed that each manual recount produces degradation of the ballots that renders a 
ideological fissures that the high court had bravely tried to paper over had become starkly apparent.

The Court's third and final intervention occurred on December 12, when it issued a per curiam opinion, also titled Bush v. Gore. ${ }^{16}$ The per curiam opinion was not signed, but it is generally thought to be primarily the work of Justice Kennedy. ${ }^{17}$ It was joined by Chief Justice Rehnquist and Justices O'Connor, Scalia, and Thomas. It held that the Florida Supreme Court's December 8 decision ordering a statewide recount violated the Equal Protection Clause of the Fourteenth Amendment and ordered the recounts to cease. It then remanded the case to the Florida Supreme Court for proceedings not inconsistent with the opinion. Since the U.S. Supreme Court held that the Florida Supreme Court could not begin the recounts again, there was literally nothing left for that court to do but dismiss the case. ${ }^{18}$ Chief Justice Rehnquist wrote a concurring opinion joined by Justices Scalia and Thomas. It argued that the Florida Supreme Court's December 8 decision also violated Article II, Section 1, Clause 2 of the U.S. Constitution, which gave the Florida legislature complete (or "plenary") power to decide the terms under which its electors would be chosen. ${ }^{19}$

Justices Souter and Breyer agreed that there was an equal protection violation but dissented from the refusal to remand for a recount. They argued that if there was a constitutional problem it should be fixed. ${ }^{20}$ Finally, Justices Stevens and Ginsburg argued that no federal law had been violated and would have upheld the decision of the Florida Supreme Court. $^{21}$

subsequent recount inaccurate; in fact, there was no evidence before the Court that such degradation was a genuine and serious problem. Nor was there a danger of misplacing ballots: The ballots were in safekeeping in the hands of the judiciary. Second, the argument is in some tension with the holding of probable success on the merits. Bush was arguing that the recounts should be stopped entirely; the very existence of the five-person majority supporting the stay strongly signaled that the purported danger of degradation of ballots was wholly irrelevant if Bush prevailed. If the Court adopted the Article II, Section 1 theory, the recounts would cease. If it adopted the equal protection theory with a December 12 safe harbor deadline, the recounts would also cease. Thus, the question of possible ballot degradation would arise only if the Court adopted an equal protection theory, did not recognize December 12 as a firm deadline, and remanded to the Florida Supreme Court for recounts before December 18-that is, the position taken by the dissenting Justices. This would hardly be a victory for Bush. Indeed, it would be a victory for Gore. Thus, Scalia's second justification for the stay looks like window dressing.

16. Bush v. Gore (Bush II), 121 S. Ct. 525 (2000).

17. Joan Biskupic, Election Still Splits Court: Friction over Justices' Ruling on Ballot Count in Florida Continues To Cause Hard Feelings, Draw Angry Letters, Even Spark Talk of at Least One Imminent Retirement at High Court, USA TODAY, Jan. 22, 2001, at 1A; Linda Greenhouse, Bush v. Gore: A Special Report: Election Case a Test and a Trauma for Justices, N.Y. TIMES, Feb. 20, 2001, at A1.

18. See Gore v. Harris, 773 So. 2d 524 (Fla. 2000).

19. Bush II, 121 S. Ct. at 534-39 (Rehnquist, C.J., concurring).

20. Id. at 545-46 (Souter, J., dissenting); id. at 551-52 (Breyer, J., dissenting).

21. Id. at 539 (Stevens, J., dissenting); id. at 550 (Ginsburg, J., dissenting). 
Thus, unlike Brown v. Board of Education and the Nixon tapes case, the decision in Bush v. Gore was far from unanimous. Indeed, it was divided along strictly ideological lines. Justices Kennedy and O'Connor proved decisive in forming a five-person conservative majority, as they have in so many other recent cases upholding states' rights, limiting federal regulatory power, and constricting federal constitutional claims. ${ }^{22}$ But their names do not appear on the per curiam order.

\section{A. The Article II Argument}

In order to understand why the case was so perplexing to most constitutional law scholars, it is necessary to go through its arguments. I begin with the argument of the three-person concurrence written by Chief Justice Rehnquist. I do this for four reasons. First, this was the argument upon which the Bush forces initially relied to overturn the Florida Supreme Court. Second, the issues in the Article II argument help set up the equal protection argument that a majority of the Court later did adopt. Third, the strongest prudential argument the Court had for intervening in the 2000 election is that the Florida Supreme Court was simply out of control and determined to throw the election to Al Gore; working through the Article II argument helps determine whether that is really so. Finally, as I explain below, the Court's equal protection theory does not really justify the remedy that the Court imposed-halting all recounts instead of remanding to the Florida Supreme Court for a uniform and equal standard for counting votes. But stopping all the recounts might make more sense under the Article II theory. Therefore it is likely that legal scholars who hope to rehabilitate the result in Bush v. Gore in the future will be particularly attracted to this line of argument. ${ }^{23}$

Chief Justice Rehnquist's argument is based on Article II, Section 1, Clause 2 of the Constitution, which provides that "[e]ach State shall appoint, in such Manner as the Legislature thereof may direct," electors for president and vice president. ${ }^{24}$ The basic idea is that the Florida legislature, and not the Florida Supreme Court, has plenary power to decide how presidential electors are chosen. If the Florida Supreme Court interprets Florida law other than "in [the] Manner" prescribed by the Florida legislature - even to avoid a conflict with the Florida Constitution-it acts in violation of the U.S. Constitution.

22. See cases cited supra note 5 .

23. See, e.g., Charles Fried, "A Badly Flawed Election": An Exchange, N.Y. REV. BooKs, Feb. 22, 2001; Richard A. Posner, Florida 2000: A Legal and Statistical Analysis of the Election Deadlock and the Ensuing Litigation (Feb. 3, 2001) (unpublished manuscript, on file with author).

24. U.S. CONST. art II, $\S 1$, cl. 2. 
The problem with Chief Justice Rehnquist's interpretation of Article II is that it assumes that one can divorce the Florida legislature from every other element of the Florida lawmaking process, including the Florida courts and the Florida Constitution, and that one can clearly separate what Florida law means from what the Florida courts say it means. This is a difficult claim to sustain. The legislature only is the legislature because the Florida Constitution creates it as such. All legislative power in Florida is subject to judicial review under the Florida Constitution and statutes are subject to ordinary judicial interpretation as well as to judicial review under the requirements of the Florida Constitution. To argue otherwise would mean that in picking electors some handful of the Florida legislators could assemble as a rump session and do almost anything they wanted, because under Article II they could not be bound by what the Florida courts or the Florida Constitution said.

The key precedent offered by the Bush camp for the plenary power of the Florida legislature under Article II, Section 1 actually cuts in both directions. In McPherson v. Blacker ${ }^{25}$ Michigan decided to divide the state into separate districts for the purpose of choosing its electors. The Supreme Court upheld this practice, arguing that the Michigan Legislature had "the broadest power of determination" to decide the method of appointing electors. ${ }^{26}$ The Court also stated, however, that "[w]hat is forbidden or required to be done by a State" in general "is forbidden or required of the legislative power under state constitutions as they exist." 27 In other words, the Court explained, "[t]he [State's] legislative power is the supreme authority except as limited by the constitution of the State." 28 Hence, if the

25. 146 U.S. 1 (1892).

26. Id. at 27.

27. Id. at 25 .

28. Id. (emphasis added). McPherson was not a case in which the legislature's decision was attacked as a violation of the Michigan state constitution. The argument was that dividing the state into electoral districts was inconsistent with Article II, Section 1 itself, $i d$. at 24, and the Court was attempting to demonstrate that the constitutional text could not possibly be read as imposing a limitation on state legislative power. The Supreme Court argued that if the Constitution had left out the words "in such Manner as the Legislature thereof may direct," it would not have limited the power of the legislature to divide its electors into districts, as long as this did not conflict with the state constitution. Id. at 25 . The addition of this language can only enhance the legislature's power, not limit it. Thus, it "operat[es] as a limitation upon the state in respect of any attempt to circumscribe the legislative power." Id. at 25. Presumably, if the Michigan state constitution took the power of choosing electors entirely away from the legislature, or specifically prohibited the division of the state into electoral districts, that would violate Article II. But it is a far stretch from this to the proposition that the legislature is not bound in any way by the state constitution when it creates election law or when it chooses electors. It is an even further stretch to the proposition that courts cannot interpret legislative election law in conformity with the state constitution. Interpretation of statutes is not an attempt to circumscribe the legislative power, especially when the court is trying to harmonize statutes with constitutional values and make the statutory scheme practical and workable. Moreover, Rehnquist's objection was not that the Florida Supreme Court was attempting to circumscribe the legislative power; he argued that any substantial change in the law violated Article II. McPherson simply does not hold this. 
Florida Supreme Court interpreted Florida's election code to make it consistent with the Florida Constitution, there would be no violation of Article II, Section 1, at least under the authority of McPherson. ${ }^{29}$

A second problem with Rehnquist's argument is that the legislature seems to have delegated the task of interpreting Florida law to Florida executive officials-for example, Secretary of State Katherine Harris-and, equally importantly, to the Florida judiciary. ${ }^{30}$ Revealingly, section 102.168 of the Florida Election Code authorizes contests of election results in the circuit courts except for elections to the state legislature, which are governed by section 102.171, in which no judicial review applies. This indicates that the Florida legislature knew perfectly well how to refrain from delegating authority to the courts when it wanted to.

The very same Florida certification and contest provisions at issue in Bush v. Gore govern both federal and state elections conducted in Florida. There is no doubt that the Florida Supreme Court has the right to interpret those provisions in state elections; why should it be prohibited from interpreting the very same provisions in federal elections? The Florida legislature did not distinguish federal from state elections in the Florida Election Code. ${ }^{31}$ Thus, if the Florida Supreme Court holds that ballots should be judged by the intent of the voter in contests over state elections, why is this test impermissible in contests over federal elections? The Florida legislature created a right to bring election contests in the Florida trial courts, which would clearly have to interpret Florida law regarding which ballots counted and which did not. Is Rehnquist arguing that Article II makes a distinction between trial courts and appellate courts, so that trial court interpretations of the law are permissible but not appellate court

29. During the arguments in Bush v. Palm Beach County Canvassing Board, several Justices actually criticized the Florida Supreme Court for construing the Florida Election Code "liberally . . . in favor of the citizens' right to vote" in light of the Florida Constitution's purposes. 121 S. Ct. at 474; United States Supreme Court Official Transcript at 52-54, 61, Bush v. Palm Beach County Canvassing Bd., 121 S. Ct. 471 (2000) (No. 00-836). The same concern is suggested in the opinion in Bush v. Palm Beach County Canvassing Board. The Court noted that "it was unclear as to the extent to which the Florida Supreme Court saw the Florida Constitution as circumscribing the legislature's authority under Art. II, § 1, cl. 2.” 121 S. Ct. at 475 . But as noted above, nothing in McPherson prevents ordinary interpretation of statutes, including harmonizing them with constitutional values, like equality or procedural fairness. Indeed, the idea that a court could not interpret statutes to promote fairness because fairness was a constitutional value seems perverse. Many constitutional values are also values that courts would routinely consider when interpreting statutes even if they were not mentioned in the state constitution.

30. See Bush II, 121 S. Ct. at 534 (Rehnquist, C.J., concurring) (citing FlA. StAT. chs. 97.012(1), 102.168(1), 102.168(8) (2000)).

31. The legislature did, however, distinguish elections to the state legislature from other kinds of state elections in section 102.171. 
interpretations $?^{32}$ This is a slender reed upon which to decide a presidential election.

Rehnquist's response seems to be that courts-including the Florida Supreme Court—can interpret Florida law consistent with Article II, Section 1, as long as their interpretation doesn't "change" the law. But this enters the realm of metaphysical speculation. Courts change law whenever they interpret it. After they decide a case, the law is different than it was before because they have resolved ambiguities and added interpretive glosses. The question cannot be whether their interpretation changes law; it is whether their interpretation is reasonable and sound. Rehnquist admits as much. At one point he suggests that the test of Article II, Section 1 is whether the Florida court's work involves a "significant departure" 33 from the prior law; at another he states that the question is whether the Florida Supreme Court "impermissibly distorted" the statutory scheme "beyond what a fair reading required." 34

Evaluating Chief Justice Rehnquist's Article II argument requires a detour into Florida election law. Florida allows protests of elections, which are held in front of county canvassing boards, and contests, which are held before courts. ${ }^{35}$ Protests ask the canvassing boards to count ballots and to count them correctly; contests challenge the validity of the election in the courts. Protests can be brought until the vote totals are certified by the canvassing boards and by the Secretary of State. After certification, parties can bring a contest of the certified results. Nothing in the language of the contest provisions, however, suggests that a protest is prerequisite to a contest. Grounds for contesting an election are given in section 102.168(3)(c). They include "[r]eceipt of a number of illegal votes or rejection of a number of legal votes sufficient to change or place in doubt the result of the election." 36

The Florida Election Code-including the protest and contest provisions-was substantially revised in 1999. Hence most of the central controversies about its interpretation were questions of first impression. This single fact already throws the Article II, Section 1 argument into considerable doubt, for unless the text was unambiguously clear, it would be hard to say that any reasonable gloss marked a "significant departure" 37

32. Cf. Bush II, $121 \mathrm{~S}$. Ct. at 534 (Rehnquist, C.J., concurring) (noting the delegation of authority to the Secretary of State and to "state circuit courts" but avoiding any mention of the Florida Supreme Court).

33. Id.

34. Id. at 535.

35. Compare FLA. STAT. ANN. § 102.166 (West 2000) (governing election protests), with id. $\S 102.168$ (governing election contests).

36. Id. $\S 102.168(3)(\mathrm{c})$.

37. Bush II, $121 \mathrm{~S}$. Ct. at 534. 
from the law, or "impermissibly distorted [it] beyond what a fair reading required." 38

In fact, the Florida Election Code was not particularly clear, and the Florida Supreme Court had to make a number of important interpretative decisions in order to apply the protest and contest provisions to the presidential election. First and foremost, the court had to decide what a "legal vote" was. The term "legal vote" is nowhere defined in the text of the statute. Chief Justice Rehnquist argued that the Florida Supreme Court's interpretation distorted Florida law because it counted what Rehnquist called "improperly marked ballots." 39 These are ballots that machine counts did not read as casting a vote for president. In effect, Rehnquist claimed, if a properly functioning punch card machine could not read a particular ballot, the ballot was not a "legal vote" under Florida law, no matter how clearly the voter's intention would seem to a human tabulator. ${ }^{40}$ Rehnquist insisted that Florida law gives detailed instructions to voters to punch their ballots clearly and cleanly. ${ }^{41}$ Therefore, he concluded, voters whose votes could not be read by punch card machines have no one to blame but themselves if the votes are not counted. They simply did not follow instructions. For this reason, the Florida Supreme Court was not entitled to interpret Florida law to let state officials inquire into the intent of the voter in order to count these "improperly marked" ballots. ${ }^{42}$ That changed and distorted Florida law.

The Florida Supreme Court disagreed. It held that "legal votes" should include votes that were not read by machine counts but that clearly indicated the intent of the voter. ${ }^{43}$ Despite Chief Justice Rehnquist's suggestion to the contrary, there is a textual justification for including these ballots. The Florida Supreme Court based its conclusion on portions of the Florida election code that controlled how canvassing boards should count votes. Section 101.5614(5) concerns ballots that are so "damaged or defective" that they "cannot properly be counted by the automatic tabulating equipment." It provides that "[n]o vote shall be declared invalid or void if there is a clear indication of the intent of the voter as determined by the canvassing board." The court reasoned that if the canvassing board must count ballots where the intent of the voter can be discerned, these are

38. Id. at 535 .

39. Id. at 537 ("Florida statutory law cannot reasonably be thought to require the counting of improperly marked ballots.").

40. For example, if the voter took the ballot and wrote on it with a Magic Marker, "I don't know whether my chad punched through correctly, but I want to vote for Al Gore," this would not be a legal vote under Florida law. I am indebted to Mark Tushnet for this example.

41. $121 \mathrm{~S}$. Ct. at 537.

42. Id. at 537-38.

43. Gore v. Harris, 777 So. 2d 1257 (Fla. 2000) ("[A] legal vote is one in which there is a 'clear indication of the intent of the voter."'). 
also "legal votes" in an election contest. This conclusion is buttressed by section 102.166(7)(b), which governs manual recounts in election protests that occur before certification. It provides that "[i]f a counting team [conducting a manual recount] is unable to determine a voter's intent in casting a ballot, the ballot shall be presented to the county canvassing board for it to determine the voter's intent." The Florida Supreme Court also noted that the intent of the voter standard for determining legal votes was hardly a novel innovation. Indeed, it had been recognized in Florida case law in cases dating back to the 1930s. ${ }^{44}$

Conversely, section 101.5614(6) provides that "[i]f an elector marks more names than there are persons to be elected to an office or if it is impossible to determine the elector's choice, the elector's ballot shall not be counted for that office." This implies that "overvotes"-where more than one name was punched on the ballot-and votes where the voter's intent could not be determined were not "legal votes." That part of the statutory text is important because the Florida Supreme Court's December 8 decision ordered the recount of undervotes, but not overvotes. Section 101.5614(6) seems to offer textual support for that approach.

Finally, because "legal votes" include undervotes that are not read by machine counts, the court held that the best way to make sense of the statutory scheme was to hold that "legal votes" are "rejected" under section 102.168(3)(c) when they are not read by a machine count. Otherwise the court would have to hold that legal votes sufficient to change the outcome of the election might exist but that failure of machines to count them could not be raised in an election contest because the votes were not "rejected," which seems to be a perverse result. ${ }^{45}$

44. Id. at 1256 (citing McAlpin v. State ex rel. Avriett, 19 So. 2 d 420 (Fla. 1944); State ex rel. Peacock v. Latham, 169 So. 597, 598 (Fla. 1936)).

45. Chief Justice Rehnquist's view that improperly marked ballots are not legal votes seems to be the view that was ultimately adopted by the Florida Secretary of State. See Bush II, $121 \mathrm{~S}$. Ct. at 537. Thus Rehnquist might argue that as a matter of administrative law the Florida Supreme Court should defer to that interpretation, akin to the Chevron doctrine, which applies in federal administrative law. See Chevron U.S.A. v. Natural Res. Def. Council, 467 U.S. 837 (1984). The problem is that Florida does not seem to have adopted the Chevron doctrine for its courts and administrative agencies, and there is nothing in Article II, Section 1 that requires it to do so. Rather, Florida seems to have adopted the rule that it will defer only to reasonable agency interpretations of statutes, and that deference is particularly appropriate only when the agency has special expertise. The Secretary of State was a political officer with no particular expertise in voting equipment; therefore it was not entirely unexpected that the Florida Supreme Court would accord her interpretation of the law less deference. See Michael J. Klarman, Bush v. Gore: Through the Lens of Constitutional History, 89 CAL. L. REV. (forthcoming Dec. 2001) (manuscript at 26) (quoting David M. Greenbaum \& Lawrence E. Sellers, Jr., 1999 Amendments to the Florida Administrative Procedure Act: Phantom Menace or Much Ado About Nothing?, 27 FLA. ST. U. L. REV. 499, 522-24 (2000)). Of course, the question of which powers are delegated to which branches of the Florida government is a question of Florida statutory and constitutional law, and Chief Justice Rehnquist gives no reason to think that prior precedents on this question were disregarded. 
Judging from the actual text of the Florida statutes themselves and the history of previous Florida decisions emphasizing the importance of discerning voter intent, one cannot say that the Florida Supreme Court's interpretation is unreasonable or significantly distorts the meaning of the statute. Indeed, Rehnquist's position seems a bit harsh and rather unreasonable, because many voters presumably do not bother to check their ballots for hanging or dimpled chads. Perhaps Rehnquist's "blame the voter" interpretation is possible, ${ }^{46}$ but it is hard to argue that it is the only plausible interpretation, or, more to the point, that it was the clear and certain meaning of the statutory scheme before the November 7 election.

The Florida Supreme Court also had to decide how much weight courts should give to decisions by the canvassing boards in election protests when a court heard a subsequent election contest. The statutory framework has separate provisions for protests and contests. The lower court judge argued that if the canvassing boards had decided not to perform manual recounts, their decision could not be challenged in a subsequent election contest unless there was an abuse of discretion. ${ }^{47}$ The statutory text does not describe contests as akin to appeals from protests or mention a standard of review. Nevertheless, Chief Justice Rehnquist agreed with this interpretation. He argued that allowing recounts during the contest phase after canvassing boards had decided against recounts "empties certification

46. Rehnquist's position on "legal votes" stems from his interpretation of section 102.166(5), which authorizes full manual recounts where a partial manual recount "indicates an error in the vote tabulation which could affect the outcome of the election." Rehnquist argues that an error in vote "tabulation" can only refer to machine error. "No reasonable person," he contends, "would call it "an error in the vote tabulation," if the voting machines fail to pick up mismarked ballots. Bush II, $121 \mathrm{~S}$. Ct. at 537. He then argues that "[i]t is inconceivable that what constitutes a vote that must be counted under the 'error in the vote tabulation' language of the protest phase is different from what constitutes a vote that must be counted under the 'legal votes' language of the contest phase." Id. at 537 n.4.

Despite Rehnquist's confident assertions, it is not obvious that "error in tabulation" cannot refer to ballots that properly working machines failed to count but that evidenced the voter's intentions. A commonsense reading of the statute would hold that machines make an "error in tabulation" whenever they fail to count legal votes that should have been counted. The error comes not from the fact that the machine is broken, but rather from the fact that machine counts are necessarily imperfect measures of voter intent. If the Florida legislature wanted to limit the phrase "error in tabulation" to errors caused by improperly functioning machines, it certainly could have done so. But the phrase is not so defined anywhere in the statute. Moreover, other parts of the statute suggest that the commonsense reading is a better one. The remedies for "error in tabulation" are not limited to fixing broken machines and running the ballots through again. They also include a manual recount of the ballots, see FLA. STAT. ANN. § 102.166(5)(c) (West 2000). Perhaps more important, under section 102.166(7)(b), the purpose of that inspection is not to determine how a properly functioning machine would have counted the ballot; it is to determine the voter's intent. Id. § 102.166(7)(b). This suggests that "errors in tabulation" may include errors that could not be corrected by machines but could be corrected only by human inspection of the ballots looking for evidence of voters' intent.

47. Gore v. Harris, 772 So. 2d at 1252 (quoting Gore v. Harris, No. 00-2808, 2000 WL 1770257 (Fla. Cir. Ct. Dec. 4, 2000)). 
of virtually all legal consequence during the contest, and in doing so departs from the provisions enacted by the Florida Legislature." 48

The Florida Supreme Court interpreted the statute differently. It did not treat election contests as an appeal from a protest but as a separate type of proceeding with a different purpose. The protest is a request for canvassing boards to perform their ministerial functions of counting votes. The contest is addressed to courts to determine whether the election was validly held, and may raise issues that go well beyond what could be raised in a protest. ${ }^{49}$ That is why a protest is not a prerequisite to a contest. It is not an exhaustion of administrative remedies. The Florida Supreme Court argued that if the plaintiffs could demonstrate that enough legal votes were not counted by the canvassing boards to change or place in doubt the outcome of the election, the court had a duty to count them even if the canvassing boards had refused. Chief Justice Rehnquist apparently believed that there was no support for this result in the text of the statute. The Florida Supreme Court's argument, however, might seem to follow directly from the language of section 102.168(3)(c), because if the canvassing board "reject[ed] a number of legal votes sufficient to change or place in doubt the result of the election" the court should not defer to its decision. Nevertheless, the court held, the canvassing board's decisions are evidence of whether a vote is legal or not. ${ }^{50}$ Although this evidence is not conclusive, "when a manual count of ballots has been conducted by the Canvassing Board ... the circuit court in a contest proceeding does not have the obligation de novo to simply repeat an otherwise-proper manual count of the ballots." 51 This does not "empt[y] certification of virtually all legal consequence"; it does, however, treat protests and contests as separate proceedings. This separation, however, seems arguably contemplated by the separate standards and procedures for contests and protests in the text of the Florida statute, and by the fact that one does not need to bring a protest first in order to bring a contest.

Finally, the court had to decide what remedies it could offer in an election contest. Section 102.168(8), also passed in 1999, states that "[t]he circuit judge to whom the contest is presented may fashion such orders as he or she deems necessary to ensure that each allegation in the complaint is investigated, examined, or checked, to prevent or correct any alleged wrong, and to provide any relief appropriate under such circumstances." 52

48. Bush II, $121 \mathrm{~S}$. Ct. at 537.

49. Gore v. Harris, 772 So. $2 \mathrm{~d}$ at 1252.

50. Id. at $1252,1260$.

51. Id. at 1260. For this reason, the Florida Supreme Court upheld the canvassing board's original manual count of ballots in Palm Beach County. Refusal to repeat manual recounts "reflects the proper interaction of section 102.166 governing protests and manual recounts and section 102.168 governing election contests." Id.

52. Fla. StAT. ANN. § 102.168(8) (West 2000). 
The construction of this statute was also a case of first impression by the courts. The Florida Supreme Court held that this statute authorized the courts to conduct manual recounts of undervotes that were not read by machines, and that it could order recounts even in counties not requested by the parties. ${ }^{53}$ Broader recounts were necessary to "correct any alleged wrong," which was the "rejection of a number of legal votes sufficient to change or place in doubt the result of the election" under section 102.168(3)(c).

Rehnquist did not object to this remedy because he thought that it was too broad or because he believed that the statutory text did not authorize it. He objected to the Florida Supreme Court's remedy because he thought that it would take too long. He believed that the Florida legislature clearly wanted to take advantage of the "safe harbor" provisions of federal law that regulate the counting of electoral votes. In 1887, Congress passed an act now codified at 3 U.S.C. $\S 5$. It provides that a state's selection of electors "shall be conclusive, and shall govern in the counting of the electoral votes" if the electors are chosen under laws enacted prior to election day, and if the selection process is completed six days prior to the meeting of the electoral college, which in 2000 was December $12 .{ }^{54}$ Section 5 thus creates a safe harbor for states to ensure that their electoral votes are counted by Congress. Note that going past the safe harbor does not mean that the electoral votes will not be counted. The safe harbor simply makes the vote count "conclusive." There are many examples of electoral votes being finalized after the safe harbor period, so missing the safe harbor deadline would hardly be an unmitigated disaster. In the 1960 election, for example, Hawaii's votes were not finalized until January $4 .{ }^{55}$ In the 2000 election,

53. 772 So. 2 d at 1253 .

54. The safe harbor provision provides:

Sec. 5. Determination of controversy as to appointment of electors

If any State shall have provided, by laws enacted prior to the day fixed for the appointment of the electors, for its final determination of any controversy or contest concerning the appointment of all or any of the electors of such State, by judicial or other methods or procedures, and such determination shall have been made at least six days before the time fixed for the meeting of the electors, such determination made pursuant to such law so existing on said day, and made at least six days prior to said time of meeting of the electors, shall be conclusive, and shall govern in the counting of the electoral votes as provided in the Constitution, and as hereinafter regulated, so far as the ascertainment of the electors appointed by such State is concerned. 3 U.S.C. \$ 5 (1994).

55. See 107 CONG. REC. 28, 291 (1961). The Hawaii story is particularly interesting. Initial returns suggested that Republican candidate Richard M. Nixon had won Hawaii, but a recount begun on December 13 gave the state to the Democrat, John F. Kennedy. Since the validity of the recount was in litigation, there were actually two sets of electors, one Republican and one Democratic, both of which met on the appointed day, December 19, 1960. The acting Governor certified the Republican electors on November 28, 1960, but a court decision at the end of December affirmed the validity of the December 13 recount. The new Democratic Governor certified the Democratic electors on January 4, 1961, shortly after taking office. Both sets of electors were submitted to Congress, with the Democratic list arriving on January 6, 1961, the day 
twenty-one states did not submit their electors to the National Archives by the December 12 deadline. These included three states-Iowa, New Mexico, and Wisconsin-in which the presidential election was particularly close. ${ }^{56}$ Four states-California, Iowa, Maryland, and Pennsylvania-did not sign the Certificates of Ascertainment establishing the identity of their electors until December 14. ${ }^{57}$ As officials at the National Archives patiently explained to reporters following the expiration of the December 12 deadline, "the reason for the seemingly slow pace" of filings with the National Archives "is that the real deadline is Dec. 18, when the members of the electoral college meet in their respective states" (and in the District of Columbia) to vote for the president and vice president. ${ }^{58}$

Nevertheless, Rehnquist asserted, the Florida legislature intended to take advantage of the safe harbor provided by federal law, and the Florida Supreme Court violated Article II, Section 1, Clause 2, because its

that the votes were to be counted before a joint session of Congress as provided for in Article II. The presiding officer at the joint session of Congress was Vice President Richard Nixon, who had just lost the 1960 presidential election but was still technically President of the Senate. Nixon stated to the joint session of Congress that he did not intend to set a precedent through his actions, but that in his view the January 4 certificate correctly stated Hawaii's votes and that if there was no objection the Democratic electoral votes would be accepted. There was no objection, and the Democratic electoral votes were counted. In fact, Hawaii's votes made no difference to the outcome of the election, which was one reason why Nixon counted them. See William Josephson \& Beverly J. Ross, Repairing the Electoral College, 22 J. LEGIS. 145, 166 n.154 (1996); L. Kinvin Wroth, Election Contests and the Electoral Vote, 65 DICK. L. REV. 321, 341-43 (1961). Congress accepted Hawaii's electors even though the certification of electors went well beyond the safe harbor period. Nevetheless, because January 4 was also well past the congressionally assigned date for electors to meet, there is a separate issue under Article II, Section 3. See infra note 58 .

56. District, 29 States Submit Electors, WASH. POST, Dec. 13, 2000, at A29; George Lardner Jr., Official Certifications of Electors Trickle In; 39 Jurisdictions File “Ascertainments," WASH. POST, Dec. 14, 2000, at A30 (noting that nine additional states filed the day after the supposed December 12 deadline); see also Savage \& Weinstein, supra note 3 ("This year, most states did not actually have the names of their electors submitted to Washington by Dec. 12.").

57. Certificates of Ascertainment are required by 3 U.S.C. $\S 6$ (1994). The Certificates of Ascertainment of the fifty states and the District of Columbia are available for inspection at http://www.nara.gov/fedreg/elctcoll/2000certa.html (last visited Feb. 19, 2001).

58. Lardner, supra note 56, at A30. This requirement is explained in the United States Code: "Meeting and vote of electors. The electors of President and Vice President of each State shall meet and give their votes on the first Monday after the second Wednesday in December next following their appointment at such place in each State as the legislature of such State shall direct." 3 U.S.C. $\$ 7$ (1994). There is a plausible constitutional argument that once Congress has set the day the states may not appoint their electors later on, because Article II, Section 3 requires that the day for choosing electors must be the same throughout the United States. The evident purpose of Article II, Section 3 is to prevent states from delaying their electoral votes in order to see what other states have done and then throw the election to one candidate or another in return for special considerations. Possibly judicial interpretation of Article II could make an exception for emergencies in which it was clear that the state was not trying to gain an advantage vis-à-vis the other states. In an age in which all states determine their electors based on popular votes on Election Day such an exception would be completely sensible. Moreover, compliance with Article II, Section 3 might be a political question reserved for Congress to decide under its powers to count electoral votes under Article II, Section 2 and the Twelfth Amendment. Either of those solutions would mean that Hawaii's 1960 vote was constitutional. 
interpretations of Florida law took Florida's election out of the federal safe harbor. Rehnquist thought the safe harbor was no longer available because the Florida Supreme Court had substantially changed Florida law as it existed on November 7, for the reasons discussed previously. Even if the Florida Supreme Court had not changed the law but only interpreted and clarified it, however, Rehnquist believed that the court-ordered recounts would take Florida out of the federal safe harbor because they might extend past December 12.

There are four problems with this objection. First, the text of the Florida Election Code is completely silent about the safe harbor deadline. The only Florida lawmaking body that had said anything about the safe harbor was the Florida Supreme Court, which Rehnquist had just accused of reading things into the text that were not there. ${ }^{59}$ Second, December 12 is not the real deadline; December 18 is. Ensuring that Florida's vote is "conclusive" is surely a valid purpose, but it is not the only purpose behind the election code. Given changed circumstances, one has to decide which purpose is more important-meeting the safe harbor deadline or counting every legal vote and attempting to discern which candidate actually received the most votes. Choosing between valid but competing purposes is a fairly standard job of courts in interpreting statutes. The text of the Florida Election Code does not decide this question, and Rehnquist and the Florida Supreme Court simply disagreed about which was more important. But that disagreement does not by itself constitute a violation of Article II, Section 1 . Third, at the very moment that Rehnquist wrote his opinion, the Florida legislature was planning to endorse a Republican slate of electors that would directly violate the safe harbor requirement because the endorsement was a change in Florida electoral law that would occur after the November 7 election. This is essentially the same cast of characters that created the 1999 Florida Election Code, and thus offers fairly strong evidence that the 1999 Florida legislature was willing to forsake the safe harbor if something more important was at stake. ${ }^{60}$ Fourth, the major impediment to completing the recounts by December 12 was the U.S. Supreme Court's stay of the recounts on December 9. The recounts were well on their way to completion when the Court stopped them. It then issued its opinion (along with Rehnquist's complaint about tardiness) at ten P.M. on December 12. It hardly seems fair to blame the Florida Supreme

59. Thus, there is something deeply ironic about Rehnquist's statement that 'the text of the election law itself, and not just its interpretation by the courts of the States, takes on independent significance" under Article II, Section 1. Bush v. Gore (Bush II), 121 S. Ct. 525, 534 (2000) (Rehnquist, C.J., concurring). If the Florida Supreme Court had not mentioned the safe harbor, Rehnquist would have had no Article II argument at all.

60. In any case, it is also likely that the 2000 legislature's act would not only violate the safe harbor provisions of 3 U.S.C. $\S 5$, but would also be in violation of Article II, Section 1 under Rehnquist's theory. 
Court for going past the safe harbor deadline when the U.S. Supreme Court held it up until the deadline was almost past.

It is interesting that Chief Justice Rehnquist does not directly object to the most obvious way that the Florida Supreme Court could be said to have changed Florida law. On November 21, the Florida Supreme Court extended the deadline for recounts in the protest phase almost two weeks and held that the Secretary of State lacked discretion to refuse to include the results of manual recounts conducted during that period in her certification of the vote totals. ${ }^{61}$ Rehnquist does not directly assert that this change violated Article II, Section 1. Rather, he uses it to undermine the Florida Supreme Court's interpretation of the appropriate standard of review of canvassing board decisions not to recount ballots. He argues that moving the deadline demonstrated that the Florida Supreme Court must have believed that certification gave "presumptive validity" to canvassing board decisions $;{ }^{62}$ otherwise it would not have shortened the contest period by lengthening the protest period. ${ }^{63}$

Why doesn't Rehnquist make more of the November 21 decision? The answer is simple. Even if the change in the certification deadline violated Article II, Section 1, the proper remedy would be to return to the certification totals that would have existed as of the statutory date of November 14. This would not prevent the Florida Supreme Court from ordering full manual recounts during the contest phase. ${ }^{64}$ In order to justify stopping the recounts completely, Rehnquist had to argue that other features of the Florida Supreme Court's decision also violated Article II, Section 1. That is why he challenged the Florida Supreme Court's interpretations of the meaning of "legal votes," the standard of review, and the importance of meeting the safe harbor deadline.

I have recounted Rehnquist's objections and the relevant features of Florida law in some detail so that the reader can judge whether the Florida Supreme Court's interpretations of the Florida Election Code were reasonable or unreasonable, or in Chief Justice Rehnquist's words, "marked a significant change" or "impermissibly distorted them beyond what a fair reading required." 65 It is hard to argue that this test is met. The Florida Supreme Court's interpretations of "legal votes" and the standard of review have a clear basis in the text of the statute, even if there are plausible contrary interpretations. Given that this was a case of first impression, one could argue that both Rehnquist's and the Florida court's interpretations

61. Palm Beach County Canvassing Bd. v. Harris, 772 So. 2d. 1220 (Fla. 2000).

62. Bush II, $121 \mathrm{~S}$. Ct. at 537.

63. Id. at 536-37.

64. It would not even prevent recounts only of undervotes. The Florida courts would simply have to excise any overvotes included in the certification.

65. Bush II, $121 \mathrm{~S}$. Ct. at 535. 
changed the law by glossing it. With respect to the remedy, the statute was simply silent on how to balance competing purposes given changed circumstances, and the Florida Supreme Court's balance of competing considerations is perfectly understandable even if Rehnquist would not have chosen it.

When one actually works through the complaints that Rehnquist makes about the Florida Supreme Court, it becomes clear that his own interpretations are not superior to theirs; in some cases his readings are markedly worse. Thus, one is left wondering: Why is Rehnquist's interpretation of Florida law more worthy of deference than the Florida Supreme Court's, especially in a case of first impression? Does he have some special expertise in Florida law that the Florida Supreme Court somehow lacks? Perhaps most importantly, why is the Florida Supreme Court's interpretation of Florida state law wrong as a matter of federal constitutional law? Perhaps Rehnquist might object that three Justices of the Florida Supreme Court agreed with him to some extent about what Florida law means, but clearly a majority did not. (He would certainly not think that four dissenting United States Supreme Court Justices conclusively determine what federal law means when a five-Justice majority disagrees). After carefully examining Florida law, one must conclude that the Article II, Section 1 argument is simply not very persuasive.

\section{B. The Equal Protection Argument}

The Bush forces originally rested their hopes on the Article II argument. Because that argument is so difficult and convoluted, however, Chief Justice Rehnquist was unable to get Justices Kennedy and O'Connor to join his opinion. Instead, they formed part of a five-person majority that decided the case on different grounds. The per curiam opinion in Bush v. Gore held that the Florida Supreme Court violated the Equal Protection Clause of the Fourteenth Amendment because it failed to impose a uniform standard for counting votes in election contests. The Florida doctrine that state officials should base their decisions on the intent of the voter was not a sufficiently clear rule. The intent of the voter test might result in different standards being invoked in different counties, or indeed, at different places within the same county. Furthermore, the certification process demonstrated that different standards actually had been used in different places. In its December 8 opinion in Gore v. Harris, the Florida Supreme Court did not correct for these discrepancies when it ordered the inclusion of different counties' manual recount totals in the official certification. In addition, in three counties, overvotes-ballots with more than one presidential choice marked-were counted in the certification totals if the intent of the voter could be determined. Yet the Florida Supreme Court's December 8 order 
for manual recounts included only those undervotes in which no choice was readable by the machines. ${ }^{66}$

Failure to have a single uniform standard meant that some votes would be counted that would not be counted if they had been inspected in different places or by different officials. The majority believed that this violated the guarantee of equal protection to the fundamental right to vote. In support of this argument, the majority cited two Warren Court precedents from the 1960s: Reynolds v. Sims, ${ }^{67}$ which established the "one person, one vote" principle, and Harper $v$. Virginia Board of Elections, ${ }^{68}$ which prohibited the use of poll taxes in state elections.

The majority's equal protection argument is novel, but not entirely crazy. It extends the principle of "one person, one vote" from the question of how districts are apportioned before the election to the question of how the votes are tabulated after the election. Just as Harper says that the states are bound by the Equal Protection Clause in establishing voting qualifications, Bush v. Gore says that states are now bound by the Equal Protection Clause in counting the votes of qualified voters. It is a large stretch in the doctrine, but it is not an impossible stretch. Of course, traditionally, states were given almost complete discretion in how they handled their electoral systems. In Colegrove v. Green, ${ }^{69}$ for example, the Court held that how the state drew its voting districts was a nonjusticiable political question. The Warren Court revolution in the 1960s changed all that. And so one could see Bush v. Gore as a further extension of federal constitutional principles into a once-sovereign prerogative of the states. It is ironic that the extension is being carried out by the Justices most committed to protecting state sovereign prerogatives against federal intrusion. ${ }^{70}$ But that speaks to the Justices' possible motives and not to the intellectual coherence of the doctrine.

66. See 772 So. 2d 1247; id. at 1264 (Wells, J., dissenting) (objecting to the refusal to count overvotes).

67. 377 U.S. 533, 555 (1964) ("[T] he right of suffrage can be denied by a debasement or dilution of the weight of a citizen's vote just as effectively as by wholly prohibiting the free exercise of the franchise.").

68. 383 U.S. 663, 665 (1966) (" $[\mathrm{O}]$ nce the franchise is granted to the electorate, lines may not be drawn which are inconsistent with the Equal Protection Clause of the Fourteenth Amendment.").

69. 328 U.S. 549 (1946).

70. See, e.g., United States v. Morrison, 529 U.S. 598 (2000) (holding that respect for state criminal and domestic law requires the invalidation of a federal civil rights statute); Alden v. Maine, 527 U.S. 706 (1999) (finding that respect for dignity of state governments requires immunity from federal rights claims against the state brought in state court); Printz v. United States, 521 U.S. 898 (1997) (noting that respect for states as sovereigns requires a Tenth Amendment prohibition on federal commandeering of state executive officials); Gregory v. Ashcroft, 501 U.S. 452, 460 (1991) (requiring a clear statement before Congress will have been judged to interfere with state governmental institutions). 
The equal protection argument faces a few problems, however. First, it is inconsistent with previous precedents that suggest that in counting, qualifying, and tabulating votes, states and localities must be given great discretion. In fact, in most equal protection cases of this nature, the Court applies only a test of rational basis; that is, it asks whether the challenged law is rationally related to a legitimate governmental purpose. ${ }^{71}$ This is especially so given that the Court did not claim that invidious motivation entered into the recount procedures. Without some proof of invidious purpose, it is difficult to see how the Florida Supreme Court's decision would have failed this test of rational basis. ${ }^{72}$ It is quite possible that the U.S. Supreme Court actually did not trust the Democratic canvassing boards and trusted recounts by Democratic judges even less, even if the latter recounts were held using a single standard. The Court did not make these accusations directly in its opinion, however. ${ }^{73}$ Perhaps the best way to solve this problem is to argue that, as in Reynolds v. Sims, the Court is interested in representative fairness as opposed to bad intent. Thus, the Equal Protection Clause demands that states must have objective standards for counting votes beyond a simple intent-of-the-voter standard because a citizen's vote should not be counted or rejected based on procedures or criteria that are arbitrary.

A more serious problem with the Court's equal protection argument is that it proves too much. Each state uses different procedures to conduct its elections, and, within states, counties, municipalities, and even precincts often use different methods of counting votes. Some use lever systems, some use paper ballots, some use punch cards, some use ATM-style machines, and some use optical scanners. The effect of all of these differences means that ballots are always treated differently at the counting phase of an election. In fact, as Justice Breyer explained, "the ballots of voters in counties that use punch-card systems are more likely to be disqualified than those in counties using optical-scanning systems." 74 This means that "in a system that allows counties to use different types of voting systems, voters already arrive at the polls with an unequal chance that their

71. See, e.g., McDonald v. Bd. of Election Comm'rs, 394 U.S. 802, 809 (1969) (stating that even in the context of the right to vote, the state is permitted to reform " "one step at a time" (quoting Williamson v. Lee Optical, 348 U.S. 483, 489 (1955))).

72. See, e.g., Lyng v. Int'l Union, 485 U.S. 360 (1988) (upholding as rationally related to a legitimate government interest a congressional decision to deny eligibility for food stamps to households in which a member was currently on strike); Transit Auth. v. Beazer, 440 U.S. 568 (1979) (upholding as rationally related to a legitimate government interest a municipal transit authority's refusal to employ former heroin addicts who used methadone). Conversely, the Court has sometimes found violations of the rational basis test where it held that invidious motivation was present. Romer v. Evans, 517 U.S. 620 (1996); Cleburne v. Cleburne Living Ctr., 473 U.S. 432 (1985); U.S. Dep't of Agric. v. Moreno, 413 U.S. 528 (1973).

73. Justice Stevens, however, reading between the lines, understood them to be implying just such accusations. Bush v. Gore (Bush II), 121 S. Ct. 525, 542 (2000) (Stevens, J., dissenting).

74. Id. at 552 (Breyer, J., dissenting). 
votes will be counted."75 And those differences in treatment swamp any differences that might accrue from slightly different standards used in manual recounts. Indeed, even when there are no manual recounts-and therefore no opportunity to apply different standards-the discrepancies created by technology are always there. So the puzzle that the Supreme Court's decision creates is why the Equal Protection Clause does not require that states create uniform technologies for counting votes rather than just uniform standards for manual recounts. The per curiam order does not say. Indeed, it specifically does not hold that technological differences among counties can give rise to an equal protection violation. Yet this is probably the greatest source of unequal treatment, particularly between more affluent counties and less affluent ones. And the irony is that when the Florida Supreme Court tried to step in to remedy the problems caused by differences in technology, the U.S. Supreme Court held that this-and not the more serious technological differences - constituted a violation of the Equal Protection Clause.

Of course, if Bush v. Gore is really a case about invidious motivation, one might be able to justify a narrower holding. Machines do not have invidious motivations; people engaged in counting ballots do. But if Bush v. Gore really is in the same honored line of cases as the ones the Court cited-Reynolds and Harper - then invidious motivation cannot be the whole story. The point of equal protection is to guarantee fairness and representativeness, and then differences in technology should matter.

The question, then, is not whether this newly crafted doctrine might make sense. The question is whether the Court is at all serious about applying it and living with its potentially revolutionary implications. If the Court were truly committed to the principle that voters should not be subjected to arbitrary procedures that decide whether their votes get counted or not, the Court would be obligated to investigate a number of different aspects of state voting practices, including technology. But the per curiam opinion deliberately shied away from these conclusions: "Our consideration is limited to the present circumstances, for the problem of equal protection in election processes generally presents many complexities." "76 This strongly suggests that the opinion in Bush v. Gore announces principles that are good for this case only. The Court in effect signaled that it had no intention of expanding the principle past the facts of this particular election contest. Nor is this surprising. The five conservative Justices who adopted the argument in the per curiam opinion are among those least likely to want to interfere with internal operations of the states

75. $I d$

76. Id. at 532 . 
on the grounds that they violate equal protection of the laws. ${ }^{77}$ Whether or not Justices Souter and Breyer would vote to extend the reasoning of Bush $v$. Gore to new situations, it remains to be seen whether any of the other Justices will. ${ }^{78}$ And if the Court does not take its newly announced equal protection principle seriously in future cases, this will cast grave doubt on how important that principle really was, other than as a means to decide the election in favor of George W. Bush. In short, what undermined belief in the Court's ability to put principle above raw partisanship was not the content of its new doctrine, but the context in which it was packaged and delivered, and the vanishingly small scope promised for the new rule.

\section{The Remedy}

The final problem with the per curiam opinion is the remedy. If the Court really thought that the equal protection violation was so serious, why didn't it simply remand the case to the Florida Supreme Court to establish a single standard for the manual recounts and then continue with the process as described under Florida law? The answer the Court gives is that this would violate another feature of the Florida statutory scheme as interpreted by the Florida Supreme Court. The Florida Supreme Court believed that the Florida legislature wanted to "participate fully in the federal electoral process," which the U.S. Supreme Court interpreted as a desire to meet the safe harbor deadline of December $12 .{ }^{79}$ The U.S. Supreme Court opinion is rather sloppy at this point. The above-quoted language does not actually

77. See cases cited in note 70 supra. One might wonder why Justices Souter and Breyer joined in the equal protection part of the opinion. This seems to be a relic of failed negotiations among the Justices. See Biskupic, supra note 17, at 1A; Greenhouse, supra note 17, at A1. Justices Souter and Breyer appear to have been engaging in a statesmanlike form of compromise. They were trying to form a coalition of Justices in the center of the Court that would recognize that there was an equal protection problem but then would send the case back to continue the recounts under a single uniform standard to be established by the Florida Supreme Court or by some other Florida official, perhaps even by the Florida Secretary of State. They were unable to persuade Justices O'Connor and Kennedy to join them. By that point, however, Justices Souter and Breyer were already committed to holding that there was an equal protection problem.

78. Justices Souter and Breyer argue that "the Equal Protection Clause does not forbid the use of a variety of voting mechanisms within a jurisdiction, even though different mechanisms will have different levels of effectiveness in recording voters's intentions." Bush II, $121 \mathrm{~S}$. Ct. at 545. The question is why this should be so, since as Justice Breyer points out in his dissent, these effects are more significant than the effects of different standards used in manual recounts. $I d$. at 552 (Breyer, J., dissenting).

79. Id. at 533 (citing "__ So. 2d, at _ 2000 WL 1800752 (slip op. at 27)" and "Palm Beach Canvassing Bd. v. Harris . . 2000 WL 1725434, *13 (Fla. 2000)"). The Court cites the wrong Florida Supreme Court opinion. 2000 WL 1800752 is the December 8 opinion in Gore v. Harris, 772 So. 2d 1243 (2000). The quoted words never appear in that opinion. They do appear in the November 21 opinion in Palm Beach County Canvassing Board v. Harris, 772 So. 2d 1220, 1237-38, 1239 (Fla. 2000), and in the December 11 opinion in Palm Beach County Canvassing Board v. Harris, 772 So. 2d 1273, 1289, 1290 (Fla. 2000), which the Court does not cite. 
appear in one of the two Florida Supreme Court cases cited, ${ }^{80}$ and the other case never mentions the December 12 deadline. The Florida Supreme Court did, however, mention the December 12 date twice in a December 11 opinion handed down after the oral argument in Bush v. Gore. ${ }^{81}$ In any case, the U.S. Supreme Court majority seized on the language of the Florida Supreme Court's opinions as a justification for ending the recounts:

The Supreme Court of Florida has said that the legislature intended the State's electors to "participat[e] fully in the federal electoral process," as provided in 3 U.S.C. $§ 5$. That statute, in turn, requires that any controversy or contest that is designed to lead to a conclusive selection of electors be completed by December 12 . That date is upon us, and there is no recount procedure in place under the State Supreme Court's order that comports with minimal constitutional standards. Because it is evident that any recount seeking to meet the December 12 date will be unconstitutional for the reasons we have discussed, we reverse the judgment of the Supreme Court of Florida ordering a recount to proceed.

Seven Justices of the Court agree that there are constitutional problems with the recount ordered by the Florida Supreme Court that demand a remedy. The only disagreement is as to the remedy. Because the Florida Supreme Court has said that the Florida Legislature intended to obtain the safe-harbor benefits of 3 U.S.C. $\S 5$, JUSTICE BREYER's proposed remedy-remanding to the Florida Supreme Court for its ordering of a constitutionally proper contest until December 18-contemplates action in violation of the Florida election code, and hence could not be part of an "appropriate" order authorized by Fla. Stat. $§ 102.168(8)(2000) .{ }^{82}$

This passage is one of the most deeply puzzling in the entire opinion. And it is the portion of the opinion where the Court's attempt to give impartial reasons for its actions fails most miserably. If the choice truly was between counting the votes the right way-that is, consistent with the

80. Supra note 79 .

81. Palm Beach County Canvassing Bd., 772 So. 2 d at 1286 n.17 (noting that 3 U.S.C. $\S 5$ "sets December 12, 2000, as the date for final determination of any state's dispute concerning its electors in order for that determination to be given conclusive effect in Congress"); id. at 1290 n.22 (noting the importance of preserving sufficient time for an election contest given the need "to accommodate the outside deadline set forth in 3 U.S.C. $\$ 5$ of December 12, 2000"). Why did the U.S. Supreme Court miss this language, which is much more relevant? In the Bush v. Gore opinion, the Justice (or clerk) who wrote the opinion accidentally cited both the December 11 case, Palm Beach County Canvassing Board v. Harris, and the December 8 case, Gore v. Harris, as $2000 \mathrm{WL} 1800752$, which is the proper Westlaw cite for Gore v. Harris. Compare $121 \mathrm{~S}$. Ct. at 528, with id. at 530, 533. Perhaps the Court was actually trying to refer to the December 11 opinion in its discussion of the remedy and simply got confused about the proper citation. If so, it is simply further evidence of how rushed the Court was in deliberating over the case and writing its opinion.

82. Bush II, $121 \mathrm{~S}$. Ct. at 533 (alteration in original) (citations omitted). 
requirements of the U.S. Constitution-and meeting the safe harbor deadline, why does it follow that the Florida Supreme Court would have interpreted Florida law as requiring that the safe harbor deadline was more important? Why not remand to the Florida Supreme Court and ask them what the best construction of Florida law was given what the U.S. Supreme Court had just done in Bush v. Gore? Why does the U.S. Supreme Court think it knows the meaning of Florida law better than the Florida Supreme Court? And why is it deferring to one part of the Florida Supreme Court's judgment about the true meaning of Florida law-the importance of meeting the December 12 deadline-but not to any other? It is hard not to notice that certain parts of the Florida Supreme Court's decisions have been picked out and deferred to as gospel while other parts are treated with complete disregard. But again, what justifies the U.S. Supreme Court's interpretation of Florida law on these grounds?

Given that the safe harbor rule is merely a convenience and not a requirement, it is hard to see why it should be more important than remedying what the Court claims to be a very serious equal protection violation. Indeed, weighing the two considerations the way the Court does tends to undermine the Court's claim that the violation was all that serious, and it makes the equal protection argument seem like a makeweight designed primarily to stop the recounts. Add the Court's offhand statement that its decision is limited to the facts before it-so that one should not expect the equal protection principle announced in Bush v. Gore to be applied to any future cases - and the suspicion becomes inescapable.

It is also at this point in the opinion that the spirit of the Article II, Section 1 argument-which O'Connor and Kennedy pointedly refused to join-seems to reemerge. The majority appears to believe that it would be wrong to "change" the law by creating a uniform standard because the safe harbor deadline would not be met. But it is not clear what the problem is. The best argument, one supposes, is that the Florida Supreme Court thought that the safe harbor was important. But that was before the U.S. Supreme Court made it impossible to meet the December 12 deadline. It is hardly clear that the Florida Supreme Court would have given the same weight to meeting the safe harbor following the U.S. Supreme Court's intervention.

Finally, there is the cursory claim that Justices Breyer and Souter really agree with the five-person majority, but simply disagree about the remedy. This is somewhat akin to saying that two doctors agree that a patient is sick, but one wants to use leeches and the other wants to prescribe antibiotics.

\section{BUSH V. GORE AND THE COURT'S INSTITUTIONAL ROLE}

Quite apart from the internal problems of legal reasoning in the opinion, Bush v. Gore seems troubling because of the way the Court 
performed its institutional role. The Court's intervention was not particularly necessary, despite the Court's insistence to the contrary. Although there are prudential arguments for intervening and stopping the recounts on December 12, they make sense only if the Court was already committed to the view that George W. Bush should have won the election. If the results of the election were in genuine doubt, and neither candidate had a stronger claim to legitimacy, then the argument for intervention becomes unpersuasive. And if one thought that Gore was the rightful winner, the arguments for intervention are perverse. Finally, and perhaps most importantly, the manner in which the Court jumped into the fray placed it in a very serious conflict of interest. It was effectively deciding who would nominate future Supreme Court Justices at a time when the Court was strongly divided between conservatives and liberals and the balance of power between them hung by a single vote.

The great Yale constitutional theorist Alexander Bickel argued that the Supreme Court should use its power of judicial review prudently, preserving its political capital for the moments in American history when it was most needed. ${ }^{83}$ Bickel thus preached what he called the "passive virtues": The Supreme Court should use procedural devices like the denial of certiorari to avoid deciding cases when the political branches might be able to work things out, especially when deciding a controversy prematurely might endanger the Court's reputation.

There are good reasons to think that Congress could have settled this dispute. Quite apart from the fact that this is Congress's constitutionally assigned job under Article II and the Twelfth Amendment, Congress passed two acts, one in 1845 and one in 1887, to deal with just such contingencies. ${ }^{84}$ Moreover, one great advantage of having Congress decide the matter is that Congress is politically accountable to the people. If people do not like how members of Congress handle the matter, they can vote those members out of office. The same cannot be said for members of the Supreme Court.

Even if judicial intervention would eventually have been necessary, the Court seemed altogether too eager to get involved. As noted previously, it jumped in the first time at the end of November and quickly discovered to

83. AleXANDER M. BiCKel, The LeAst DANGerous BranCH: THE Supreme COURT AT THE BAR OF POLITICS 173, 235, 264 (2d ed. 1986); AleXANDER M. BiCKEL, THE SuPREME COURT AND THE IDEA OF PROGRESS 94-95 (1978) [hereinafter BICKEL, PROGRESS] ("[T] here is a natural quantitative limit to the number of major, principled interventions the Court can permit itself. ... A Court unmindful of this limit will find that more and more of its pronouncements are unfulfilled promises, which will ultimately discredit and denude the function of constitutional adjudication."); Alexander M. Bickel, The Supreme Court, 1960 Term-Foreword: The Passive Virtues, 75 HARV. L. REV. 40, 75 (1961).

84. Act of Jan. 23, 1845, 28 Cong. ch. 1; 5 Stat. 721; Act of Feb. 3, 1887, 49 Cong. ch. 90, 24 Stat. 373. These are now codified at 3 U.S.C. $\S \S 1-15$ (1994). 
its chagrin that its decision would be irrelevant. ${ }^{85}$ Its December 9 stay essentially decided the election and strongly signaled that the Court had made up its mind about the result and was simply looking for a rationale on which to rest its conclusions. And both of these interventions came not because of any direct right of appeal, but through the Court's discretionary power to grant or deny writs of certiorari. For this reason, the final words of the per curiam opinion ring particularly hollow:

None are more conscious of the vital limits on judicial authority than are the members of this Court, and none stand more in admiration of the Constitution's design to leave the selection of the President to the people, through their legislatures, and to the political sphere. When contending parties invoke the process of the courts, however, it becomes our unsought responsibility to resolve the federal and constitutional issues the judicial system has been forced to confront. ${ }^{86}$

There was simply nothing "unsought" about the Court's actions in Bush v. Gore. Indeed, Bush v. Gore is almost a parody of the Bickelian notion of judicial restraint. In Bush v. Gore the Supreme Court restrained virtually everything in sight: It restrained the Florida Supreme Court; it restrained the democratic process; and above all it restrained the counting of votes. Bickel taught that in controversial cases the Court should stay its hand, while Bush v. Gore held that in controversial cases the Court should hand out a stay. ${ }^{87}$

The argument for restraint, however, depends on how grave a threat the constitutional order faces, and how seriously fundamental rights have been compromised. If the threat is serious enough, the Court should get involved. Political capital should be expended when something important is at stake. Moreover, as I argue in Part V, it is not at all clear that the Court expended any political capital by deciding the case. Indeed, it may have increased it, at least in the eyes of congressional Republicans.

85. David Strauss has argued that the Court was so eager to hear the case in late November that it misread the provisions of 3 U.S.C. $\S 5$, assuming that they were mandatory requirements about how electors must be chosen rather than merely a "safe harbor." David A. Strauss, Bush v. Gore: What Were They Thinking?, 68 U. CHI. L. REV. (forthcoming 2001) (manuscript at 12-13, on file with author). This misunderstanding is reflected in the grant of certiorari in Bush v. Palm Beach County Canvassing Board, 121 S. Ct. 510 (2000). By the time of the oral argument in Bush v. Palm Beach County Canvassing Board, several Justices appear to have seen their mistake, and the argument shifted instead to Article II, Section 1 as the constitutional objection to the Florida Supreme Court's decisions. Strauss sees this episode as evidence that the more conservative Justices were casting about for a way to end the election early on. Id. (manuscript at 13-14).

86. Bush II, 121 S. Ct. at 533.

87. Instead of Bickel's passive virtues, the Court adopted what might be called the "passiveaggressive virtues." See Mark A. Graber, The Passive-Aggressive Virtues: Cohens v. Virginia and the Problematic Establishment of Judicial Power, 12 CONST. COMMENT. 67, 67 (1995). 
The best prudential defense of the Court's intervention is that the Court saw the election as a serious political crisis. It believed-or rather five Justices believed-that the Florida Supreme Court was an out-of-control activist court that was trying to steal the election for Al Gore. The Court knew that, whatever it did, it would be heavily criticized. So it decided to fall on its sword and expend some of its political capital in order to stabilize the situation and save the nation.

Was the Court's decision a statesmanlike decision to prevent an out-ofcontrol partisan Florida Supreme Court, or was the decision itself the product of partisan politics? In the previous discussion of the Article II, Section 1 argument, I showed at some length that the Florida Supreme Court's interpretations were eminently reasonable, even if they were not the only possible interpretations. If so, it is hard to argue that the Court's intervention was necessary. There simply was no lawless court for the U.S. Supreme Court to counteract, just a court that construed its own local law in a way that five Justices did not like.

Moreover, if the Florida Supreme Court was truly a partisan body that was out of control, and determined to hand the Presidency to Al Gore at all costs, several of its decisions seem puzzling. For example, it had the opportunity to throw out thousands of absentee ballots from Republicans in which the voters did not fill in all of the statutorily required information. ${ }^{88}$ Instead the Florida Supreme Court held that even though the statutory requirements listed in the Florida Election Code were technically necessary, ballots that did not meet the statutory requirements were not illegal. In fact, it specifically refused to adopt a straightforward reading of the Election Code that would have essentially guaranteed a Gore victory. ${ }^{89}$ This seems like a court devoted to the proposition that recording voters' intentions is

88. Jacobs v. Seminole County Canvassing Bd., 773 So. 2d 519 (Fla. 2000); Taylor v. Martin County Canvassing Bd., 773 So. 2 d 517 (Fla. 2000). Voter identification numbers were filled in by Republican party workers in violation of the statutory requirement that "the person making the request" provide the information. FlA. STAT. ANN. § 101.62 (West 2000); Jacobs, 773 So. 2d at 521.

89. See Jacobs, 773 So. $2 d$ at 522 . The Court held that "[t]he statutory requirement" that the person requesting the absentee ballot "'must' disclose the nine items in [Fla. Stat.] Section 101.62(b) [(2000)]" was "simply not a definitive statement by the Legislature that requests which are missing the voter's registration number are illegal or void." Id. If the Court had wanted to void the absentee ballots, and secure a victory for Al Gore, presumably it could have held that the word "must" means "must." Instead, it read section 101.62(b) against another part of the Florida Election Code which stated that absentee ballots would be "illegal" if they failed to contain certain information. See FLA. STAT. ANN. § 101.68(2)(c)(1) (West 2000). Since section 101.62(b) does not specifically say that nonconforming absentee ballots are "illegal," they can still be counted. In the court's words, the requirements of section 101.62(b) are directive, but not mandatory. Id. That reading makes sense if the Court's driving principle was preserving the legality of as many absentee ballots as possible, even though most of those ballots were Republican. 
the paramount concern of the Florida election law. It does not sound like a court whose robust partisanship has blinded it to all reason..$^{90}$

In any case, a simple thought experiment, along the lines suggested by Michael Klarman, can help resolve the question whether the U.S. Supreme Court's intervention is best explained by the Florida Supreme Court's partisanship or its own. ${ }^{91}$ Suppose for a moment that the positions of the parties were reversed. Suppose that the Florida vote had initially gone for Gore on November 7, that Bush had called to concede but then retracted his concession, and had begun a protest and a contest of the Florida results. Suppose further that the Secretary of State was cochairman of Gore's presidential campaign in Florida, and issued the same interpretations of Florida law as Katherine Harris did, although now to Gore's benefit. Suppose the Florida legislature, now controlled by Democrats, was threatening to appoint its own slate of Democrat electors, egged on by the Democratic governor of Florida, who just happened to be Al Gore's brother. Then suppose that the Florida Supreme Court was stocked not with Democrats but Republicans, and that they issued the exact same opinions with the exact same interpretations of Florida law, adopting the intent of the voter standard and ordering a statewide manual recount of ballots.

Now imagine that Gore's attorney-the well-known liberal law professor Laurence Tribe-appeared before the U.S. Supreme Court and argued (1) that the Court should not defer to the Republican-controlled Florida Supreme Court because the interpretation of Florida election law was a federal, not a state question; (2) that the Court should extend liberal Warren Court precedents concerning legislative redistricting to state tabulation of ballots; and (3) that the Court should immediately shut the Republican Florida Supreme Court's recounts down because of the paramount importance of the federal safe harbor rule. Does anyone think that the result would have been the same? One can just imagine the look on Justice Scalia's face as Tribe argued that the Florida state courts were lawless and should be subjected to federal supervision under Article II, Section 1 and the Equal Protection Clause. Indeed, one is almost certain that a majority of the Court would have would have found these arguments highly implausible if delivered on Gore's behalf. If so, then the justification for the Court's intervention cannot be that the Florida Supreme Court was unduly partisan and out of control, for the interpretations would be just as crazy and just as partisan if offered by Republicans as by Democrats. ${ }^{92}$

90. I note in passing that Chief Justice Rehnquist did not complain about this change in Florida law as a violation of Article II, Section 1.

91. Klarman, supra note 45 (manuscript at 5-6, 31).

92. Chief Justice Rehnquist and Justices Scalia and Thomas would almost certainly have rejected the Article II argument if Gore's attorney had made it. After all, Gore's position would have permitted federal scrutiny of state court constructions of state law. Justices O'Connor and Kennedy did not like the Article II argument when it benefited Bush; there is no reason to think 
One might object that what matters is not whether the Florida Supreme Court was actually out of control or partisan judged from some objective standpoint, but whether the Republican Justices in the Bush v. Gore majority honestly believed that the Florida Supreme Court was out of control. Given their beliefs they did what they thought was best for the country. But in that case the reasonableness of the Court's intervention fades away. For it concedes that the Supreme Court found the Florida Supreme Court partisan not because intervention was genuinely reasonable or necessary but because they themselves were shaped by their own partisanship. The success of this prudential argument cannot be divorced from political ideology.

One can make the prudential argument for intervention in a different way. If the Court had not stopped the recounts, the Florida legislature might have produced its own slate of electors. As a result, votes from more than one slate might have traveled to Washington. The Congress would then have had to decide between them on January 6. Each side would have accused the other of stealing the election. Partisan infighting would have been especially bitter. Most political observers believed that congressional Republicans would have been especially determined to wrest control at any cost. ${ }^{93}$ Republicans hungered to regain control of the presidency after eight

that they would like it better when it benefited Gore. In fact, my suspicion is that in a hypothetical Gore v. Bush case, the Article II argument would have lost 9-0.

The equal protection argument might have fared better: Justices Souter and Breyer were willing to find an equal protection violation in Bush v. Gore, so it stands to reason that they would be hospitable to a Gore equal protection argument in a hypothetical Gore v. Bush. Stevens and Ginsburg applied existing understandings of equal protection law in their dissents. Would they have joined Souter and Breyer if Gore had argued for a significant extension of equal protection doctrine? I cannot say. Stevens is notoriously unpredictable, while Ginsburg has shown herself to be a fairly cautious jurist outside of the area of sex discrimination. There is no reason, however, to think that an equal protection argument made by Gore would have attracted Rehnquist, Scalia, and Thomas. Justice Scalia, in particular, has stated quite forcefully that state practices that have a long tradition of acceptance should not be disturbed by novel theories of equal protection. See, e.g., United States v. Virginia, 518 U.S. 515, 568 (1996) (Scalia, J., dissenting). Justices O'Connor and Kennedy seemed highly suspicious of the all-Democratic Florida Supreme Court, and Justice O'Connor made her displeasure known on the bench. United States Supreme Court Official Transcript at 43-44, Bush v. Gore, 121 S. Ct. 525 (2000) (No. 00-949). They would be much less suspicious of an all-Republican Florida Supreme Court trying to ensure that every legal vote for George W. Bush was counted. If so, Gore would probably not get five votes for his equal protection argument. Perhaps the more important question is whether in a hypothetical Gore v. Bush scenario, five Justices would have believed that the appropriate remedy for an equal protection violation was to stop all recounts, instead of remanding to the Florida Supreme Court. This seems implausible in the extreme. Indeed, I do not think this proposed remedy would have received a single vote.

93. See, e.g., Susan Baer, GOP Right Unleashes Its Wrath on Gore; Conservatives Vow Gridlock if He Wins, BALT. SUN, Nov. 21, 2000, at A1 (noting that "Republicans are more indignant about the possibility of a Gore presidency than Democrats are about a possible Bush victory," and noting the conservative threat that if Gore wins, "[i]mpeachment proceedings will start the day of the inauguration"); George E. Condon Jr., GOP Frustration over Recounts Is Turning to Anger, SAN DIEGO UNION-TRIB., Nov. 23, 2000, at A13 (quoting a statement by a Republican operative that Republicans have "a very, very deep anger out there-they are really 
years. As a group they despised Bill Clinton and loathed his scandal-ridden administration. Congressional Republicans impeached Clinton and tried to throw him out of office in 1998, and many of them never fully accepted the legitimacy of his presidency. With the presidency up for grabs in 2000, they may well have overreacted and behaved very badly indeed. It was possible that whatever the Congress did would be seen widely as the rawest form of politics, with no concern for fairness or justice. This would have delegitimated the new president and prevented him from governing effectively. Hence the danger of reckless and delegitimating behavior by Congress (and by outside agitators), although not certain to occur, was sufficiently great for the Court to intervene before Congress got involved. It was far better to stop the recounts and hand Bush the presidency than to cripple the next president.

This prudential argument makes the most sense if George W. Bush was going to be president in any case. If the Florida legislature nominated its own slate of electors, and if the congressional Republicans muscled the Democrats out of the way, the overtly political nature of the fracas might well poison the atmosphere and harm Bush's legitimacy. But suppose one thought that Gore was the rightful winner, and that the Republicans were trying to steal the election. After all, Gore won the popular vote by half a million votes, and if the recounts proceeded he might have won Florida as well. (Even if one thinks that Florida was a statistical tie, Gore's lead in both the popular vote and in the electoral college exclusive of Florida would speak in favor of his legitimacy.) Then the argument for handing the presidency to Bush rather than Gore because of a fear that the Florida legislature would substitute their judgment for that of the Florida voters and that the congressional Republicans would go nuclear is not very persuasive. Indeed, the idea that the Court should hand the presidency over to the person who obtained fewer votes nationwide because his party threatened to misbehave seems a perversion of democratic principles. It would also be a remarkable indictment by the Republican Justices of their own party. To be sure, in other times and places people have given in to fascists, communists, and terrorists because of fear of their violence and thuggery, but one hopes that the contemporary Republican Party is not yet in the same company. In fact, there is every reason to believe that cooler heads would have prevailed

ticked off.... I don't think it has ever been this deep. It makes impeachment look like kindergarten"); Eric Pianin \& Juliet Eilperin, An Angry GOP on Hill Would Confront Gore if He Won, WASH. POST, Nov. 20, 2000, at A8 (quoting a Senate Democratic leader as stating that "[t]he depth of resentment and the extraordinary hostility the Republicans already have demonstrated towards the vice president is far greater than the somewhat mild opposition that Democrats have expressed about Bush"); Talk of the Nation (NPR radio broadcast, Dec. 14, 2000) (comments of Columbia University History Professor Alan Brinkley) ("I believe that ... the dynamics of this contest had gotten to a point where Republicans simply were never going to concede this race no matter what the vote total said."). 
and the proceedings would have been acceptably civil and restrained-in the manner of the Senate's impeachment trial of Bill Clinton which had occurred less than two years before. Both parties would understand that the voters might hold them responsible in 2002 and 2004 if they acted outrageously. This is, of course, one of the great advantages of having representative institutions-rather than the Court-decide who becomes president. $^{94}$

Equally important, the prudential argument does not take into account the likely change in public reaction that would have occurred if Gore pulled ahead in court supervised recounts. Gore could then claim that he had won a majority in Florida and a majority in the electoral college as well as a majority in the popular vote. Public support would surely have coalesced around a candidate who had won the election in three different ways. The Republicans would have judged it politically very difficult to displace him with Bush, and their opposition on January 6 might have been much less fierce. ${ }^{95}$ Indeed, in some scenarios, moderate Republicans would probably have pressured Bush to concede once the judicial appeals of such a recount had been exhausted. ${ }^{96}$

The "crippled presidency" scenario also seems to assume an inevitable Bush victory. If Gore-who, it cannot be stressed too often, actually won the popular vote-had prevailed in Congress despite the best efforts of the Florida legislature and congressional Republicans, it is not at all clear that

94. The congressional "train wreck" scenario might be extended to a concern about civil unrest. There is simply no evidence, however, that there would have been riots in the streets or widespread civil disruptions if the Court had allowed Congress to settle the issue. Although there were a number of demonstrations, the period following the November 7 election was remarkable for the lack of violent upheaval in the general population. Indeed, the only riots during the period following the 2000 election appear to have been staged in the offices of the Miami-Dade canvassing board by House Majority Whip Tom DeLay for the purpose of preventing the canvassing board from counting the votes. See Dana Canedy with James Dao, Contesting the Vote: The Demonstrators; How the Troops Were Mobilized for the Recount, N.Y. TIMES, Nov. 28, 2000, at A26; Nicholas Kulish \& Jim Vandehei, Bush Campaign Pays Tab for Capitol Hill Aides Flown In for Rallies, WALl ST. J., Nov. 27, 2000, at A40; Paul Lomartire, GOP Sent T-Shirt Team of Dedicated Infiltrators, PALM BEACH POST, Dec. 1, 2000, at A1; David Sarasohn, GOP Imports D.C. Staff Protesters: Takin' It to the Suites, OREGONIAN, Nov. 29, 2000, at D11.

95. During the brief period between the Florida Supreme Court's December 8 decision and the Supreme Court's December 9 stay, Republican congressmen were openly contemplating a Gore victory in Florida. At that point they were much less certain whether they could maintain public support for their position if Gore pushed ahead in the recounts. See Richard L. Berke, Contesting the Vote: The Strategies; Stunned Republicans Vow Fight to End, N.Y. TIMES, Dec. 9, 2000, at A1 ("[S]everal [Republicans] acknowledged for the first time since the election a month ago that they feared that Mr. Gore could become the president."); see also Adam Clymer, Contesting the Vote: Congress; The Detours (and Monsters) Along the Electoral Road, N.Y. TIMES, Dec. 9, 2000, at A11 ("[A] senior Republican, speaking anonymously, said he was 'absolutely' certain that some Republicans would desert their party if they believe Mr. Gore had really won more votes.”).

96. If the U.S. Supreme Court had taken the case and remanded for recounts under a single uniform standard on December 12, Republicans would have found it very difficult to press Bush's case if Gore pulled ahead. Once Gore was declared the winner under a recount judged legally fair, public support for Bush might well have collapsed. 
he would regard his presidency as crippled. (One need hardly add that the fear that congressional Republicans might give him a hard time as president is no reason to deny him the office.) If Gore won a recount in Florida as well as the popular vote nationwide, many Americans would have seen his victory as a simple vindication of majority rule. Gore might well use this fact to combat any Republican claims of illegitimacy. The congressional Republicans would simply have had to grin and bear it for the next four years, much as the congressional Democrats must do now.

In sum, the prudential arguments for short-circuiting Congress and stopping the contest on December 12 are path-dependent. They are more persuasive if one is already committed to a Bush presidency. They are less persuasive-indeed, singularly unpersuasive-if one believed that Gore won or that the outcome was genuinely in doubt. To be sure, Bush's election looks more inevitable to the public once he is situated in the Oval Office and people become accustomed to him as president. But the Court acted long before that happened. It acted on December 9, when it seemed that Gore was about to prevail. Hence prudential considerations cannot justify what the Court did, except, of course, to Bush supporters.

Most of the institutional arguments for intervention or restraint seem to cut both ways under the facts of Bush v. Gore. The Court should intervene in sufficiently worthy causes, and whether this was a worthy cause has much to do with one's view about whether there was a crisis that required the Court's intervention. That question, in turn, depends largely on who one thought the president should be. Whether the Court should have intervened, however, does not seem to turn on whether one thought there actually was a serious equal protection violation, since the Court was not particularly interested in remedying it.

I think that there is a much more important complaint to be made about the Court's institutional role. The problem is not whether the Court should have expended political capital but whether the Court faced a serious conflict of interest. In particular, the Court's decision to intervene offended the basic principle that one should not be a judge in one's own case. It mattered a great deal to the Justices who became president. And in Bush v. Gore they were given the rare chance to reverse Mr. Dooley's famous maxim that the Supreme Court follows the election returns. ${ }^{97}$ They were able to make the election returns follow the Supreme Court.

Much was made during the days immediately before and after the second Bush v. Gore argument about the possible conflicts of interest that several Justices had. Justice Scalia's son worked at the same law firm as Theodore Olson, who represented the Bush team before the Court. Justice Thomas's wife was employed by the Bush transition team. Neither of these

97. Finley PETER DunNe, Mr. DoOley AT HIS BeSt 77 (Elmer Ellis ed., 1949). 
two conflicts is particularly important; at most they demonstrate that Scalia and Thomas are well connected to conservative elements within the Republican Party, which should surprise no one. But the most important conflict of interest applied to all of the Justices. By effectively deciding who would become the next president, they were also effectively deciding who would appoint their replacements and future colleagues. It was widely speculated that Chief Justice Rehnquist and Justice O'Connor had been considering retirement in the next four years. They would much rather retire under a Republican president than a Democratic one. ${ }^{98}$ Moreover, the Rehnquist Court has decided a very large number of issues 5-4 in recent years, with five conservatives trumping four liberals on issues ranging from state's rights to affirmative action. ${ }^{99}$ A Democrat would appoint people who might undo much of the Court's recent work; a Republican would probably appoint people who would extend the work of the conservative majority. Finally, the new president would be able to stock the lower federal courts with ideological allies. Because the Supreme Court takes relatively few cases, the Justices have a considerable interest in making sure that their decisions are being interpreted and applied by people who think roughly as they do. ${ }^{100}$

The Court is often faced with situations where the interests of Justices are at stake. In cases where judicial pay raises are litigated, all judges benefit from a pay raise. The rule of necessity allows them to take the case, because no one else can. ${ }^{101}$ In cases like Cooper v. Aaron ${ }^{102}$ or City of Boerne v. Flores, ${ }^{103}$ the question is whether the Court should assert its supremacy over the other branches, and as members of the judiciary all of the Justices might be seen as facing a conflict of interest. But Bush v. Gore presents a very different type of conflict. Although all of the Justices faced the same type of conflict of interest, it pointed in different directions for different Justices. The conservatives appeared to have reasons to appoint

98. See, e.g., Biskupic, supra note 17 , at $1 \mathrm{~A}$. The widely circulated story that "O'Connor became visibly upset [at an election night party on November 7] when network anchors first said Gore had won the critical state of Florida," and that "[h]er husband told others at the party that his wife was concerned because the couple wanted to retire and that she preferred a GOP president name her successor" may or may not be true, although it has been confirmed by a variety of sources close to the Court. Id. It is hardly news, however, that Justice O'Connor and Chief Justice Rehnquist have contemplated retirement in the next few years.

99. See cases cited supra note 5.

100. George W. Bush has recently decided to end the fifty-year practice of submitting judicial nominations to the American Bar Association before they are publicly announced. The presumed reason for the decision is to make it easier to nominate far more ideologically conservative people to the federal judiciary. Neil A. Lewis, White House Ends Bar Association's Role in Screening Federal Judges, N.Y. TIMES, Mar. 23, 2001, at A13.

101. See, e.g., United States v. Will, 449 U.S. 200, 213-216 (1980); Mitchell v. Sage Stores Co., 143 P.2d 652, 656-58 (Kan. 1943); Philadelphia v. Fox, 64 Pa. 169, 84-186 (1870).

102. 358 U.S. 1 (1958).

103. 521 U.S. 507 (1997). 
Bush as President; the liberals Gore. The situation is perhaps closest to a lawsuit between two corporations where five Justices own stock in the petitioner and four own stock in the respondents, and the case is decided for the petitioner 5-4. Unless there are pressing reasons to take the case, the best solution is to deny certiorari and just say no. Among the other prudential factors, the conflict of interest for the Justices in Bush v. Gore should have weighed more heavily than it did, because it might call (and it did call) the Court's impartiality seriously into question. It presented the most important reason for the Court to stay out of this particular controversy.

\section{BUSH V. GORE, LEGAL REALISM, AND CRITICAL LEGAL STUDIES}

Jurisprudentially speaking, the big winners of the 2000 election were American Legal Realism and Critical Legal Studies. Ironically, by the election of 2000, both traditions were largely submerged in the American legal academy. Critical Legal Studies was dead as a doornail, and the insights of legal realism had long since been coopted and domesticated.

Legal realism, which developed primarily at Yale and Columbia during the 1920s and 1930s, was a response to the reactionary decisions of courts at the turn of the century. The realists argued that judges are heavily motivated by their political philosophy and their innate sense of right and wrong. Facts matter more than doctrine, which can often be reshaped to fit the facts as judges see them. ${ }^{104}$ As Justice Oliver Wendell Holmes-a hero to many of the realists - once said, the life of the law has not been logic but experience. ${ }^{105}$ Hence judges should be more open and honest about their politics and their view of the world and not try to hide behind legal mumbo jumbo.

Critical Legal Studies, which was developed at Harvard and several other law schools during the 1970s and 1980s, was a reaction to the conservative legal and political retrenchment that followed the election of 1968. Critical Legal Studies scholars (or "crits," as they came to be known), argued that law is a highly specialized and distinct form of political reasoning, relatively autonomous from ordinary political struggle, that must

104. The literature on American Legal Realism is vast. For useful introductions, see AMERICAN LEGAL REALISM (William W. Fisher III et al. eds., 1996); NEIL DUXBURY, PATTERNS OF AMERICAN JURISPRUDENCE (1995); LAURA KALMAN, LEGAL REALISM AT YALE: 1927-1960 (1986); WILFRID E. RUMBLE, JR., AMERICAN LEGAL REALISM: SKEPTICISM, REFORM, AND THE JUdiCIAL PROCESS (1968); JOHN H. SCHLEGEL, AMERICAN LEGAL REALISM AND EMPIRICAL SOCIAL SCIENCE (1995); WILliam L. TWINING, KARL LlEWELlyN AND THE REALIST Movement (1973); Robert W. Gordon, American Law Through English Eyes: A Century of Nightmares and Noble Dreams, 84 GEO. L.J. 2215 (1996); and Edward A. Purcell, American Jurisprudence Between the Wars: Legal Realism and the Crisis of Democratic Theory, 75 AM. HIST. REV. 424 (1969).

105. Oliver WeNDELl HOLMES, JR., THE COMMON LAW 1 (1881). 
mystify or disguise its political content as doctrinal or rule-based reasoning. ${ }^{106}$ Because lawyers and judges can often find more than one way to characterize and interpret legal doctrines, they can often find ways to advance their ideologies through legal argument and still sincerely claim to be upholding the rule of law. Hence the law will often end up benefiting the most powerful forces in society, whether or not justice is on their side. ${ }^{107}$ Ultimately, the crits argued, the legal system can be legitimized only by the actual justice it produces, not through giving lip service to legal rules or engaging in pious platitudes about the legal process. The crits believed that faith in legal process and legal craft values were not enough, because these also were deeply shaped by politics and ideology. One could not rely on craft or process alone to produce a fair legal system or to save the legal system from corruption, injustice, and abuse.

In one sense, Bush v. Gore looks like strong confirmation of both legal realism and Critical Legal Studies. The Justices used the forms of legal argument to arrive at a particular result that suited their respective political ideologies. But the situation is more complicated than this. Both legal realism and Critical Legal Studies assume that judges do not leave their ideologies behind when they construe law. Rather, they see law through the lens of what they regard as fair and just, and they shape the principles and doctrines of law in the direction in which the law already appears to them. ${ }^{108}$ Yet in Bush v. Gore the members of the Court did not seem to be promoting a particular ideological vision through their opinions. Indeed, it was the conservatives who were making the equal protection argument and extending Warren Court precedents; it was the liberals who were urging deference to the states' legal processes. Instead, in Bush v. Gore, ideology's influence manifested itself in a more troubling way: The members of the Court seemed to be arguing for a more narrow, partisan result. The conservatives used whatever arguments were available to promote George W. Bush's election, while the liberals offered the arguments that would

106. The relative autonomy of law from politics was as central to Critical Legal Studies as it was to critics of the movement. The two sides simply disagreed about what this relative autonomy meant in practice and how far it extended. For examples of the relative autonomy thesis in Critical Legal Studies, see MORTON J. HORWITZ, THE TRANSFORMATION OF AMERICAN LAW, 17801860, at xiii (1977); MARK Kelman, A GUIDE TO CRITICAL LEGAl STUdies 249-51 (1987); Robert W. Gordon, Critical Legal Histories, 36 STAN. L. REV. 57, 88-93 (1984); Mark V. Tushnet, Critical Legal Studies: A Political History, 100 YALE L.J. 1515, 1525 n.41 (1991); and Mark V. Tushnet, Perspectives on the Development of American Law: A Critical Review of Friedman's A History of American Law, 1977 WIS. L. REV. 81, 82-94.

107. For an excellent introduction to Critical Legal Studies approaches, see Robert W. Gordon, Unfreezing Legal Reality: Critical Approaches to Law, 15 FLA. ST. U. L. REV. 195 (1987). See also DunCAN KenNedy, A CRitiQue of AdJudicAtion: Fin DE SiÈCLE (1997) (attempting to establish a critical position on the relationship between law and politics in adjudication).

108. See KENNEDY, supra note 107; J.M. Balkin, Ideology as Constraint, 43 STAN. L. REV. $1133(1991)$. 
have helped Al Gore. This is a more overt collapse of the boundary between law and politics than Critical Legal Studies would normally predict, although it is perhaps consistent with cruder forms of legal realism. ${ }^{109} \mathrm{In}$ short, in Bush v. Gore the Court did not even preserve the relative autonomy of law from politics that Critical Legal Studies assumed.

In fact, given the implausibility of much of the Bush v. Gore opinion, one could argue that the opinion is actually a refutation of legal realism and Critical Legal Studies. Under this view, Bush v. Gore is simply a sport, an example of temporary failure that conveys nothing about the legal system as a whole. Sometimes judges make mistakes, and sometimes they betray their oaths of office, but this conveys nothing about whether the legal system as a whole cannot adequately separate law from the most partisan forms of politics. Indeed, one might argue that both legal realism and Critical Legal Studies are incorrect because any reasonable person, any well-trained lawyer can see that the Court made hash of legal reasoning in Bush v. Gore. It follows that if the Court had been willing to be constrained by its proper role and by sound values of legal craft and principled legal reasoning, then it would have been wholly unable to do what it did. Critical Legal Studies scholars argued that judges disguise or mystify the political content of legal decisionmaking through the forms of legal argument. But in Bush v. Gore this mystification utterly failed. Any well-trained lawyer can see through what the Court did. Hence Bush v. Gore must be seen as an outlier rather than as symptomatic of the way that courts actually function. It is simply an unfortunate fact that this legal sport determined the outcome of a presidential election.

I think this argument ultimately does not hold water. First, the argument assumes that there was no way that the Justices could have reached the same result through plausible legal argument. But that hardly seems impossible to achieve. The argument would only have to be plausible given existing conventions of legal craft. It would not have to convince everyone-most legal arguments rarely do that. Much of the implausibility of Bush v. Gore is due to the lack of time the Court gave itself to decide the case. If the Justices had enough time, there is no doubt in my mind that the five conservatives could have come up with a more plausible way to stop the election and hand the presidency to George W. Bush, even if it was on different grounds. The mere fact that a given opinion is not persuasive does not mean that cleverer legal minds with more time on their hands cannot come up with better versions, and, when this occurs, law professors usually see this as a vindication of the original decision. Indeed, there is a cottage industry among liberal law professors devoted to rewriting cases like Roe $v$.

109. See Levinson, supra note 4 , at 8 . 
Wade $^{110}$ and Brown v. Board of Education ${ }^{111}$ that seem to have been inadequately reasoned. ${ }^{112}$ Roe is a particularly good example: Liberal and feminist legal scholars have spent decades showing that the result was correct even if Justice Blackmun's opinion seems to have been taken from the Court's Cubist period. ${ }^{113}$ When the Supreme Court struck down Colorado's Amendment 2 in Romer v. Evans ${ }^{114}$ in 1996, legal scholars rushed to explain why the result was correct even if the logic of Justice Kennedy's opinion seemed rather sparse and undernourished. ${ }^{115}$ I do not doubt that very bright conservative legal scholars will be able to rewrite Bush v. Gore to make it make sense to them, if not to their more liberal Democratic colleagues. That project, I expect, is already well under way.

Second, the argument assumes that the reasoning of Bush v. Gore is simply "off the wall" from the standpoint of what any well-trained lawyer could accept. But the question of whether a legal argument is "on the wall" or "off the wall" is a matter of social practice and convention. Many eminent members of the legal academy and the bar, and a handful of Supreme Court Justices, thought that these arguments were not only plausible but convincing. Theodore Olson, who has won a number of cases before the Supreme Court, obviously thought the arguments he offered in Bush v. Gore were not "off the wall." At least two members of the Harvard Law faculty thought so too, ${ }^{116}$ not to mention the Chief Justice of the United States and four of his colleagues. The question of what is "off the wall" and what is "on the wall" in law is tied to a series of social conventions that include which persons in the legal profession are willing to stand up for a particular legal argument. In law, if not in other disciplines of human thought, authority, and particularly institutional authority, counts for a lot. The more powerful and influential the people who are willing to make a legal argument, the more quickly it moves from the positively loony to the positively thinkable, and ultimately to something entirely consistent with

110. 410 U.S. 113 (1973).

111. 347 U.S. 483 (1954).

112. For an example, see WHAT BROWN, supra note 10, in which nine constitutional scholars try their hand at rewriting Brown.

113. See Mark V. Tushnet, Following the Rules Laid Down: A Critique of Interpretivism and Neutral Principles, 96 HARV. L. REV. 781, 821 (1983).

114. 517 U.S. 620 (1996).

115. See, e.g., Akhil Reed Amar, Attainder and Amendment 2: Romer's Rightness, $95 \mathrm{MICH}$. L. REV. 203 (1996); Lynn A. Baker, The Missing Pages of the Majority Opinion in Romer v. Evans, 68 U. COLO. L. REv. 387 (1997); Daniel Farber \& Suzanna Sherry, The Pariah Principle, 13 CONST. COMMENT. 257 (1996).

116. See Einer Elhauge, Bush v. Florida, N.Y. Times, Nov. 20, 2000, at A27 (arguing that manual counts had no objective and clear standards, thus anticipating the equal protection argument made in Bush v. Gore); Fried, supra note 23 (defending the result on Article II, Section 1 grounds). 
"good legal craft.""117 This feature of legal argument may be deeply unsettling to many nonlawyers, but it is another way of understanding the point of Critical Legal Studies and legal realism.

Moreover, the brute fact of the decision in Bush v. Gore has a curious bootstrapping effect. It makes the arguments in that case no longer "off the wall." At the very least, it makes them much less "off the wall" than they would have been before December 12, 2000. That is because the decision in Bush v. Gore will now be cited in courts and taught in law schools as the law. Lawyers and law professors will do their best to work the case into the corpus of existing precedents. The work of harmonization and rationalization will proceed apace, and one of its side effects is that what gets harmonized and rationalized over time is no longer considered "off the wall." This, too, is a familiar feature of law and legal practice. After the 1973 decision in Roe v. Wade, for example, the argument that the word "liberty" in the Fourteenth Amendment includes a woman's right to have an abortion was no longer "off the wall." Nor was the argument that the viability of the fetus should be the line that determines the scope of that right. After Roe v. Wade, these claims simply became plausible for the well-trained lawyer, even if she was not ultimately convinced by them. After Reynolds v. Sims ${ }^{118}$ and Baker v. Carr, ${ }^{119}$ the argument that the Court should intervene in the political processes of the states became more thinkable. That is a feature of law's dual character as both reason and fiatas a set of reasoned arguments and a set of doctrines created and laid down by government officials.

Third, the question of whether a legal argument is "on the wall" or "off the wall" - that is, the conditions of its plausibility-are not wholly divorced from political ideology. The model of legal craft as an effective constraint on legal argument suggests that the conventions of legal craft create a recognizable boundary that separates what is good legal argument from what is bad or incompetent legal argument. Within this boundary liberals and conservatives may disagree about what arguments are more or less plausible. But the boundary itself keeps both sides from straying into the wildly implausible or incompetent. This idea of controllable boundaries of legal rhetoric is a familiar theme in American jurisprudence. The legal

117. For example, although there was a well developed antislavery jurisprudence that argued that slavery was unconstitutional before the Civil War, the view of most well-trained lawyers was that these arguments were ridiculous and therefore "off the wall." See J.M. Balkin \& Sanford Levinson, The Canons of Constitutional Law, 111 HARV. L. REV. 963, 1023-24 (1998); Randy E. Barnett, Was Slavery Unconstitutional Before the Thirteenth Amendment?: Lysander Spooner's Theory of Interpretation, 28 PAC. L.J. 977 (1997); Lysander Spooner, The Unconstitutionality of Slavery, 28 PAC. L.J. 1015 (1997) (featuring excerpts from Spooner's THE UNCONSTITUTIONALITY OF SLAVERY (B. Franklin 1965) (1860)).

118. 377 U.S. 533 (1964).

119. 369 U.S. 186 (1962). 
process theorists of the 1950s emphasized the role of craft in constraining lawyers and judges, while Owen Fiss argued famously in the 1980s that "disciplining rules" kept courts in line. ${ }^{120}$

As necessary as this model may be to an everyday understanding of legal practice, it is nevertheless seriously flawed. Conservatives draw the boundary of plausibility differently than liberals, and vice versa. That is why Theodore Olson and the Bush legal team were able to come up with their arguments in the first place. The Warren Court's decisions in the 1960s looked to legal conservatives as made up out of whole cloth just as the activist decisions of the current conservative majority look made up to people schooled in the Warren Court's jurisprudence. What makes a legal argument a good one or a bad one can itself become a bone of political contention, the specialized form of political contention carried out through the forms and practices of legal argument. Put another way, the boundaries of good legal argument are not fixed for liberals and conservatives alike. They are themselves a potential subject of contestation by and through legal argument.

As a teacher of constitutional law, I have been predicting the outcome of Supreme Court decisions for most of my professional career. This requires me, among other things, to predict not only how each individual Justice will vote, but what direction the Court will move in and what legal and political constraints shape that movement. During the last five years or so, I have been consistently wrong about what the Court was willing to do to promote its conservative agenda. Repeatedly-in cases like City of Boerne v. Flores, ${ }^{121}$ which struck down the Religious Freedom Restoration Act, and United States v. Morrison, ${ }^{122}$ which struck down the Violence Against Women Act-I have thought to myself: "They can't possibly do that. That would be crazy." And each time I have been proven wrong. These recalcitrant experiences suggest to me that my own judgment about what is "on the wall" and what is "off the wall," what is a good legal argument and what is wholly implausible is slowly but surely moving out of the mainstream, if that mainstream is defined by the actual holdings of the United States Supreme Court. My sense of what is possible and plausible, what is competent legal reasoning and what is simply made up out of whole cloth is probably mired in an older vision of the Constitution that owes much to the Warren and Burger Courts as well as to the predominantly liberal legal academy in which I was educated, trained, and now teach. Finally, I should note that as soon as each of these new Supreme Court decisions is handed down, dozens of bright young constitutional lawyers

120. Owen M. Fiss, Objectivity and Interpretation, 34 STAN. L. REV. 739, 744-47 (1982).

121. 521 U.S. 507 (1997).

122. 529 U.S. 598 (2000). 
busily begin to rationalize it, showing how it is, after all, completely consistent with the text, structure, original intentions, values and traditions of the American Constitution. For these legal scholars, opinions like Boerne and Morrison are not off the wall. They are the wall.

\section{BUSH V. GORE IN THE CONSTITUTIONAL CANON}

How will Bush v. Gore be received in the legal academy in the long run, and how will it be taught in the future? This is a question of particular interest for me. I edit a constitutional law casebook, and one of my abiding interests is the formation of the legal canon. ${ }^{123}$

Three things might happen to Bush v. Gore. One possibility is that the case will be rationalized. Lawyers, judges, and law professors will try to fit it into existing doctrinal structures and then try to pursue its possible extensions and ramifications into law. ${ }^{124}$ As I have noted, this is one of the most important ways that tensions created by legal decisions are smoothed over and doctrines are made part of the accepted corpus of legal argument. This process of rationalization is already afoot. Law professors and other legal scholars are already trying to make a silk purse out of this particular sow's ear. ${ }^{125}$ Revamping the Article II, Section 1 argument will probably be the choice of many defenders, because it is easier to justify the remedy. ${ }^{126}$ As we have seen, if one is serious about the equal protection argument, it is difficult to justify failing to remand the case. On the other hand, if one accepts the Article II, Section 1 argument, the appropriate remedy is to return to the certified vote totals which resulted from machine counts, and no further counting is necessary. ${ }^{127}$

I suspect that many other scholars, especially those on the left, will try to conceptualize Bush v. Gore as part of the equal protection jurisprudence of voting. ${ }^{128}$ So interpreted, Bush v. Gore will constitutionalize the way that

123. See Legal CANONS (J.M. Balkin \& Sanford Levinson eds., 2000); Balkin \& Levinson, supra note 117.

124. Mark Tushnet, Renormalizing Bush v. Gore, 90 GEO. L.J. (forthcoming Nov. 2001).

125. E.g., Fried, supra note 23; Posner, supra note 23.

126. This is the tack taken by both Charles Fried and Richard Posner. See supra note 23.

127. The issue is actually somewhat more complicated, because the certified 537-vote lead for Bush included some manual recounts in selected counties, in addition to various absentee ballots of dubious legality under the then existing Florida statutory scheme. If one wanted to achieve the count that would have occurred if Florida law had been strictly adhered to without any changes, the Court would not be able to stop the recounts. Rather, it would have to determine whether the Florida Supreme Court could, consistent with Article II, Section 1, accept absentee ballots that were not properly filled out and postmarked according to law, on the ground that they reflected the intent of the voters who cast them. See supra text accompanying notes 88-90. If those absentee ballots were thrown out, it is conceivable that Gore might have won by a considerable margin under the Article II, Section 1 theory of the case.

128. E.g., Samuel Issacharoff, The Court's Legacy for Voting Rights, N.Y. TIMES, Dec. 14, 2000, at A39 ("The lasting significance of Bush v. Gore is likely to be the reinvigoration of the 
votes are counted and what kinds of voting systems are constitutionally permissible. As noted previously, that is certainly a possible trajectory of the holding of the case. The problem is that it would require a significant intervention into state governmental processes. The five conservatives who handed Bush the presidency have strongly supported states' rights in the past. ${ }^{129}$ For this reason I doubt whether a majority of the Supreme Court is really serious about taking the principles of Bush v. Gore further than the 2000 election. In that case, the decision is much more likely to be regarded as a sport, a one-shot case, with no continuing precedential impact. People will rationalize it by treating it as sui generis. ${ }^{130}$

A second possibility is that people will forget the case, in part because it cannot easily be rationalized with existing law, and in part because the case is an embarrassment. After a while, no one will study it but legal historians. Law students will not learn it in their constitutional law classes, because it does not fall into the standard categories that law students learn in their constitutional law courses. ${ }^{131}$ Judges and lawyers will no longer cite it because it has no continuing precedential effect. The best analogy would be the series of cases known as the Legal Tender Cases: Hepburn $v$. Griswold, ${ }^{132}$ Knox v. Lee, ${ }^{133}$ and Juilliard v. Greenman. ${ }^{134}$ In Hepburn, the Court held that the national government could not constitutionally issue paper money (or "greenbacks") as legal tender. This was a great embarrassment to the Republican Party, which had used paper money to help finance the Civil War. The decision was 5-3; five Democrats were in the majority, and three Republicans were in the dissent. Shortly after the decision in Hepburn was announced, one of the Democratic Justices in the majority retired and the Congress increased the size of the Supreme Court to nine Justices. The new president, Ulysses S. Grant, appointed two

line of cases from the 1960's that deemed voting a fundamental right. . . The legacy of this case could be a substantial jolt of justice into the voting arena.").

129. See, e.g., cases cited supra note 70 . As Justice Ginsburg dryly remarked, "[w]ere the other members of this Court as mindful as they generally are of our system of dual sovereignty, they would affirm the judgment of the Florida Supreme Court." Bush v. Gore, 121 S. Ct. 525, 549-50 (2000) (Ginsburg, J., dissenting).

130. See Tushnet, supra note 124 (manuscript at 3-5). Tushnet compares this process to quantum physicists who remove anomalous infinities from their calculations so that the calculations can reach a desired conclusion. Tushnet's claim is "that legal elites would like to renormalize the anomalous decision in Bush $v$. Gore so that we can return to our belief that law is sensibly distinguished from politics." Id. (manuscript at 3 ).

131. Those standard categories in most first year constitutional law courses are: (1) judicial review, (2) federalism, (3) separation of powers, (4) the Fourteenth Amendment (not including voting rights), and (5) the First Amendment. Bush v. Gore is a voting rights case and therefore would be less likely to be included in a standard first-year course, unless the professor had other reasons for teaching it. As a case about Article II, Section 1, Clause 2, it would have even less of a hold on the canon as it is currently organized.

132. 75 U.S. (8 Wall.) 603 (1869).

133. 79 U.S. (12 Wall.) 457 (1870).

134. 110 U.S. 421 (1884). 
Republicans to fill the vacant seats, creating a new five-person Republican majority. The Court then searched for a new legal tender case to reconsider Hepburn, and a year later, it overturned Hepburn by a 5-4 majority in Knox $v$. Lee, once again splitting along party lines. Knox held that greenbacks could be legal tender if there was a showing of emergency. Finally, in 1884, the Court held in Juilliard that the entire issue of paper money as legal tender was a political question and therefore beyond the purview of the courts. Because the switch from Hepburn to Knox in a single year could only be explained by the shift in personnel, it tended to show the Court as fairly clearly motivated by politics. The Legal Tender Cases have fallen out of the canon in part because the Federal Reserve Board now controls monetary policy, but also because they were an embarrassment to the Court's prestige. They showed the Court in its most political light. ${ }^{135}$

A third possibility is that Bush v. Gore will be remembered, but as part of what Sanford Levinson and I call the "anti-canon."136 In the literary canon, one usually remembers only the greatest works. But one of the interesting things about the legal canon is that it includes particularly dishonored examples of legal decisions as well as particularly honored ones. Infamous and unjust cases like Dred Scott v. Sandford ${ }^{137}$-which held that blacks could not be citizens-Plessy v. Ferguson ${ }^{138}$ — which gave constitutional blessing to Jim Crow-Korematsu v. United States ${ }^{139}$ which justified the internment of Japanese-American citizens-and Lochner v. New York ${ }^{140}$ — which wrote laissez faire into the Constitutiontend to be remembered as examples of how courts should not behave. Bush v. Gore could become part of the canon in this way. It could stand as an object lesson in what courts do and do not do, what they should do and should not do.

I believe that remembering the Court's failures and injustices is every bit as important as remembering honored cases like Brown v. Board of Education. The casebook that I edit with Paul Brest, Sanford Levinson, and Akhil Amar ${ }^{141}$ has for many years devoted more attention to the constitutional questions concerning chattel slavery than any other casebook.

135. For a discussion of the political background to the Legal Tender Cases, see PAUL BREST, SANFORD LEVINSON, J.M. BALKIN \& AKHIL AMAR, PROCESSES OF CONSTITUTIONAL DECISIONMAKING 231-37 (4th ed. 2000); and Kenneth W. Dam, The Legal Tender Cases, 1981 SUP. CT. REV. 367.

136. See Balkin \& Levinson, supra note 117, at 1018; J.M Balkin \& Sanford Levinson, Interpreting Law and Music: Performance Notes on "The Banjo Serenader" and "The Lying Crowd of Jews,” 20 CARdozo L. REV. 1513, 1553 (1999); see also Richard A. Primus, Canon, Anti-Canon, and Judicial Dissent, 48 DUKE L.J. 243, 245 (1998).

137. 60 U.S. (19 How.) 393 (1856).

138. 163 U.S. 537 (1896).

139. 323 U.S. 214 (1944).

140. 198 U.S. 45 (1905).

141. BREST, LEVINSON, BALKIN \& AMAR, supra note 135. 
One reason for this is precisely that everyone now understands slavery to have been a great evil. It was a great evil that was sustained and perpetuated through constitutional arguments made by some of the finest legal minds that America had to offer. Law students need to understand how welltrained lawyers acting in good faith could have participated in such a system and rationalized it according to well accepted modes of legal argument, justifying their work in the name of America's great charter of democracy, liberty, and equality. ${ }^{142}$ We have recently brought the Legal Tender Cases back into the casebook so that students understand that the uncomfortable relationship between party politics and Supreme Court reasoning is perennial. Indeed, I think that the Legal Tender Cases are a much better analogy to Bush v. Gore than cases like Dred Scott or Lochner. In the Legal Tender Cases and in Bush v. Gore, the consequences of judicial decisionmaking are more overtly partisan.

\section{BUSH V. GORE AND THE LEGITIMACY OF THE SUPREME COURT}

I close by considering how Bush v. Gore has affected the Supreme Court's legitimacy. Courts are among the most trusted institutions in American public life. What effect will Bush v. Gore have on that trust? My answer is that in the long run the decision in Bush v. Gore will make little difference, although in the short run, the Court's legitimacy is in play, depending on what the political branches do.

The Court's legitimacy is often described in terms of its "political capital." 143 The term "political capital" is generally not defined. It is likely that it has many facets. One element of political capital might be the likelihood that people will follow the Court's decisions and treat them as binding law, especially in controversial cases. Yet if the question is merely whether the Court's decisions will be obeyed, it seems clear that its capital was hardly damaged at all. No one doubted for a second that Al Gore would obey the Court's order, or that the Florida Supreme Court would cease the recounts immediately. The Court's ability to command obedience remains largely unaffected by Bush v. Gore. There is little doubt that people will continue to follow the Supreme Court's decisions. Lawyers will continue to cite them, and lower courts and legal officials will continue to apply them as before. Thus, if legitimacy or political capital means only brute

142. See id. at xxxii.

143. See, e.g., JESSE H. CHOPER, JUdicial REVIEW AND THE NATIONAL POLITICAL PROCESS, 139, 162, 169 (1980) (speaking of the Court's public prestige and institutional capital); Erwin Chemerinsky, The Supreme Court, Public Opinion, and the Role of the Academic Commentator, 40 S. TEX. L. REV. 943, 943, 948 (1999); Jesse H. Choper, The Scope of National Power Vis-à-Vis the States: The Dispensability of Judicial Review, 86 YALE L.J. 1552, 1552, 1580 (1977). Bickel inspires this approach, although he does not use the expression "political capital." See BICKEL, PROGRESS, supra note 83, at 94-95. 
acceptance of the Court and its decisions as a going concern, the Court will not lose any legitimacy as a result of its decision in Bush v. Gore.

If the Court's political capital is judged by whether politicians are wellor ill-disposed toward the Supreme Court, then the Supreme Court may well have increased its political capital in the short term by halting the recounts. ${ }^{144}$ After all, there is now a Republican president, and Republicans control both houses of Congress. They are no doubt delighted with the Supreme Court's exercise of judicial review, for it guarantees them a period of one-party rule. As a result, they are probably much more favorably disposed to granting the Justices the pay raise that Chief Justice Rehnquist has been requesting for several years. ${ }^{145}$ Judged in raw political terms, the Supreme Court made much more powerful friends than enemies when it decided Bush v. Gore. ${ }^{146}$

Nevertheless, legitimacy might mean something more than the two senses of "political capital" that I have just described. When people speak of "legitimacy"- not in a rigorously philosophical sense but in an everyday sense of the word - they are often referring to basic questions of trust and confidence in public officials: Do people believe that public officials are honest and trustworthy, and do they have confidence that public officials will act in the public interest and not for purely partisan or selfish reasons? These forms of legitimacy are crucial to the courts because the courts rely so heavily on the appearance of fairness and reasonableness. To be sure, sometimes people speak of "moral legitimacy"-whether what government officials do is in fact just and fair-and "procedural legitimacy" - whether government officials have employed fair procedures. But often people do not know what government officials are doing-for example, most people do not read judicial opinions - and even then what is actually just and fair is often difficult to determine. So in practice when people speak of a court's

144. I am indebted to Sanford Levinson for this point.

145. WILLIAM REHNQUIST, 2000 YEAR-END REPORT ON THE FEDERAL JUDICIARY 2-7 (2001), available at http://www.supremecourtus.gov/publicinfo/year-end/2000year-endreport. html; Associated Press, Lawyers Say Federal Judges Need Pay Raises, ST. LouIS POSTDisPATCH, Feb. 13, 2001, at A9; Frank J. Murray, Groups Back Rehnquist's Call To Increase Judges' Salaries, WASH. Times, Feb. 13, 2001, at A8; Jonathan Ringel, U.S. Judicial Pay Raise Movement Picks Up Steam in Washington, N.J.L.J., Feb. 12, 2001.

146. The argument that courts should conserve political capital in order to do "the right thing" when it is necessary assumes that doing "the right thing" is likely to expend political capital. The paradigm case might be Brown v. Board of Education. But views about what "the right thing" might be are not independent of ideological and party affiliation. Republicans wanted the Court to do "the right thing" in Bush v. Gore and stop the lawless Florida Supreme Court. By avoiding a political train wreck, or, in Gerald Ford's famous words, putting an end to our long national nightmare, the Court might actually increase and solidify support among like-minded constituencies. Moreover, even if a decision is controversial when first handed down, if the decision is ratified or accepted by the public in the short run-as the Nixon Tapes Case was - the Court's reputation can be enhanced. Note, finally, that although Brown v. Board of Education cost the Supreme Court considerable political capital in the South in the short run, in the longer run the decision burnished the Court's reputation considerably in the nation as a whole. 
"moral legitimacy" or "procedural legitimacy," they may not mean whether courts actually are fair and just but whether people believe that they are fair and just. According to this analysis, moral and procedural legitimacy are elements of trust and confidence in public officials - in this case, trust and confidence that these officials are upright and honest and will do the right thing.

Understood in this broader sense, the question of the Court's legitimacy concerns whether people will continue to have faith in the Court as a fairminded arbiter of constitutional questions, whether they trust the Court, whether they have confidence in its decisions, and whether they believe its decisions are principled and above mere partisan politics. That sort of confidence and trust probably has been shaken, particularly among lawyers and legal academics, but also in portions of the public at large.

Even so, the effects of Bush v. Gore on the Court's legitimacy may differ markedly for different populations and social groups. Perhaps trust and confidence have been damaged among Democratic voters-who are a sizeable proportion of the population - and within the legal academy, which tends to be liberal. But in other groups, the evidence of a loss of faith is quite mixed. Republican politicians like Tom DeLay and Trent Lott probably now have renewed confidence in the Court. After Bush v. Gore, they know that they can rely on the Court to do the right thing (in all the different senses of the word "right"). Although liberal legal academics have been badly shaken by the decision, conservative legal academics have come to the Court's defense, and one expects that we will see more spirited endorsements in the future. ${ }^{147}$ Finally, most Americans are not privy to the niceties of constitutional argument and so may not be able to judge whether the Court has played fast and loose with the law. Indeed, the polling data do not seem to suggest a sharp drop off in the Court's approval ratings. A Gallup Poll conducted from January 10 to 14, 2001, indicated that 59\% of those surveyed approved of how the Court was handling its job while $34 \%$ disapproved, only a three percentage point drop from its $62 \%$ approval rating in a similar poll taken from August 29 to September 5, 2000, long before the Florida controversy occurred. ${ }^{148}$ Make no mistake: Many people are very, very angry at the Supreme Court, and the Court probably has lost their trust and confidence. But these citizens may not constitute a majority

147. David G. Savage, The Vote Case Fallout: Ruling Could Harm Respect for Court and Its Federalism Decisions, 87 A.B.A. J. 32 (2001) (quoting John Yoo and Marci Hamilton in defense of the majority's decision); Talk of the Nation (NPR radio broadcast, Dec. 20, 2000) (comments of Professor Charles Fried defending Bush v. Gore); see also supra note 23.

148. See Wendy W. Simmons, Election Controversy Apparently Drove Partisan Wedge into Attitudes Towards Supreme Court (Jan. 16, 2001), at http://www.gallup.com/poll/releases/ pr010116.asp. In the January poll, the Court's negative rating increased by five percentage points to $34 \%$, with $7 \%$ expressing no opinion, down two points from $9 \%$ in the August-September poll. Id. 
of all Americans. Perhaps more importantly, the persons who are currently in power like what the Court is doing just fine.

In any case, there is no doubt in my mind that the Supreme Court will eventually regain whatever trust and confidence among the American public that it lost in Bush v. Gore. The Supreme Court has often misbehaved and squandered its political capital foolishly. It has done some very unjust and wicked things in the course of its history, and yet people still continue to respect and admire it. If the Court survived Dred Scott v. Sandford, it can certainly survive this.

But that is a long-run estimate. The short run, which I see as the next four to five years, is somewhat different. Because people disagree about the fairness of the 2000 election, the Court's legitimacy is in play. In the short run, its legitimacy is dependent on the other branches of government in ways that it has not been for some time. How people feel about the Court will turn on how they feel about the Bush presidency, because the Court effectively put Bush in office. And how people feel about Bush depends on what the Congress does and how well Bush behaves. This is an interesting moment in American history precisely because the Court's legitimacy is much less in its own hands than it usually is.

If the American people like and accept George W. Bush, then they will tend to explain his election as legitimate because the election was effectively a tie. But if people dislike Bush, or lose trust and confidence in his abilities as President, then the opinion that he does not deserve to hold office will increase. That will increase the popular sense of frustration at the Court that put him in office. Although there is no reason logically why an unpopular or incompetent president should be regarded as having less of a right to hold office than a popular or competent one, the different forms of legitimacy do affect each other in practice, because all of them in one way or another concern people's psychological attitudes toward government officials. Hence a loss in one facet of legitimacy tends to cause a loss in the others as well. If Bush proves to be inefficacious, or if he cannot inspire confidence, people will begin to doubt the procedural legitimacy of his election and the moral legitimacy of his right to rule. And this loss of legitimacy will have ramifications for the Supreme Court.

The connection I have just drawn between the legitimacy of the presidency and the legitimacy of the Court is not accidental. It flows from important features of the American constitutional system that distinguish it from other systems of democratic governance, including, most importantly, parliamentary systems. Those same features suggest what the appropriate remedy for Bush v. Gore is under the American Constitution and what strategies are available to the Democrats to respond to what the Supreme Court did in Bush v. Gore. 
The American Constitution does not, strictly speaking, contemplate the possibility of an illegitimate president. The Twenty-Fifth Amendment is concerned with a president who is "unable to discharge the powers and duties of his office,"149 and the impeachment and removal clauses of Article II permit Congress to remove a president who has committed high crimes and misdemeanors. Nevertheless, aside from the scenario in which a vice president might try to seize power by claiming that the president is disabled (a contingency which is the one of the central concerns of the Twenty-Fifth Amendment), the possibility that a president might be installed by a coup, judicial or otherwise, does not seem to have been explicitly provided for in the Constitution.

If Bush v. Gore had occurred in a parliamentary system, a quick remedy for the Court's behavior would be relatively easy to provide. George W. Bush would be a prime minister with only the narrowest margins of control in his country's Parliament. Currently, Republicans control the U.S. House of Representatives by only nine votes, and the Senate is split evenly. Therefore, Bush would probably have been subjected to an endless series of no-confidence motions, and at some point he would have been forced to call for new elections. If Bush and his party had won a larger majority, his legitimacy would have been bolstered and confirmed. If he had lost the election, the opposition would have taken over. Politics would have solved the problem of legitimacy, as it does so often in parliamentary systems.

The American system, however, is not a parliamentary system. It is based on a fixed constitutional calendar. ${ }^{150}$ The president serves for four years, regardless of which party controls the House and Senate. House representatives serve for two years, and senators for six, regardless of who resides in the Oval Office. As a result, American politicians face a very different set of incentives than their counterparts in parliamentary systems. They know that once a president is installed, there is nothing they can do to get rid of him for four years, other than impeach and remove him. The recent experience of the Clinton impeachment demonstrates, if any demonstration were necessary, that this is extremely hard to do. The Democrats have fifty Senators, not sixty-seven, and so they cannot use impeachment as a ready substitute for a vote of no-confidence even if they wanted to. ${ }^{151}$

Because George W. Bush has been installed as president for four years, the Democrats must bide their time. They cannot bring a series of no-

149. U.S. CONST. amend. XXV.

150. This remarkable feature of American constitutionalism, and many of its consequences, have been well described by Bruce Ackerman. See, e.g., 2 BRUCE ACKerman, We THE PeOPle: TRANSFORMATIONS (1998); Bruce Ackerman, The New Separation of Powers, 113 HARV. L. REV. 633 (2000).

151. Nor would this be a particularly good use of the impeachment power. 
confidence motions, and they cannot bring down his government, as they no doubt would attempt in almost any other democracy in the world. This fact leads many to assume that the Bush Presidency is fully normal and that the Democrats should just "get over it" and accept Bush's authority as fully presidential in all respects. But this misunderstands the distinctive features of American democracy and the distinctive nature of the American constitutional calendar. It is true that the Democrats must wait. But this does not mean that there is nothing that they can do. Nor does it mean that they must treat Bush as if he had won the popular vote by five million votes instead of having lost it by five hundred thousand. The very same features of the fixed constitutional calendar that prevent them from bringing down Bush's government also determine their best strategy. They can attempt to regain the House and Senate in 2002, and the presidency in 2004. If they succeed in shifting control of both the executive and legislative branches from Republicans to Democrats in only four years, they will have delivered as strong a rebuff to Bush v. Gore as is possible under the American system of government, and one suspects that they will soon be able to stock the judiciary with Democrats as well. In that case, the repudiation of Bush v. Gore will be complete. An unexpected benefit of the American system is that, although it does not explicitly countenance illegitimate presidents, it does provide a remedy for them through the processes of normal politics. That remedy is complicated and slow, to be sure, but it exists nonetheless.

One should not overestimate the adequacy of the political remedy that the Constitution provides. One of the most worrisome features of Bush v. Gore is that it leveraged Republican control of the judiciary to secure control of another branch. ${ }^{152}$ Because of the decision of the five conservatives in Bush v. Gore, Republicans have won the constitutional trifecta: They now control all three branches of government, and they can use that control to help them remain in power in the future. For example, once George W. Bush is in the White House, his chances for election to a second term are greatly enhanced simply because he is the incumbent. And, as already noted, a Republican president is much more likely to appoint conservative Republicans to the federal bench than a Democrat would be.

The Democrats are quite fortunate that the 2000 election produced a House and Senate that are so evenly split. That fact, more than anything else, gives them a realistic chance to regain control of one or both Houses in the next two elections, and a realistic chance to contest any of George W.

152. Thus, Bush v. Gore presents an unusual variation of the problem of partisan entrenchment noted in the famous footnote four of United States v. Carolene Products, 304 U.S. 144, 152 n.4 (1938). See J.M. Balkin, The Footnote, 83 Nw. L. REV. 275 (1989). According to Carolene Products, one purpose of judicial review is to prevent political factions or parties from passing legislation that will entrench their political power and make it more difficult to dislodge them. By contrast, in Bush v. Gore the five conservatives used the power of judicial review to entrench further their party in power. 
Bush's Supreme Court nominees. If the margins of Republican control were not so razor thin in both houses, the Democrats would be in deep trouble. If, for example, Bush v. Gore had occurred after the 1994 elections-when the Democrats were very much in the minority in both Houses-the Court could have relegated the Democrats to many years in the political wilderness.

Thus, the fixed constitutional calendar merely provides an opportunity for remedy, it does not guarantee it. George W. Bush may turn out to be just as popular a president as he was a popular governor of Texas. The Republicans may hold on to both houses of Congress, and even increase their representation. Therefore, even if Bush's presidency is tainted by the Supreme Court's unwise intervention, it is up to the Democrats to convince the American people that they deserve to regain power.

George W. Bush's best strategy for consolidating his power is to govern as if he has the right to govern. The Democrats, on the other hand, must work hard to undermine popular trust and confidence in the President and the Republican Party. One way of doing this is by raising a fuss about things that presidents normally get as a matter of course. The prolonged struggle over the nomination of John Ashcroft to be attorney general is a good example. It is best understood as a warning shot across the bow-an indication that the Democrats will not treat this new administration as completely normal in all respects.

That is where the Supreme Court comes in. The Democrats in Congress will also have much to do with how the Court is perceived in the short run. They may try to make the Court an issue, either by holding up judicial appointments or effectively blocking new appointments to the Supreme Court. They can repeatedly remind people that the Court decided the election and play up the Court's conflict of interest in choosing the president who would choose the Justices' colleagues and successors. Finally, if the Democrats use the controversy over the election to help them win Congress in 2002 and the presidency in 2004, the political branches will no longer be so friendly. The Court will lose much of the political capital it gained when Republicans controlled everything. These effects, however, are largely out of the Court's hands, for it has already put Bush into office. The Court will reap what it has sown.

Of course, the Court is not a completely passive actor. It can also affect its legitimacy through its own actions. For example, Justice O'Connor or Chief Justice Rehnquist can precipitate a brouhaha by deciding to announce their retirements at a particularly politically inappropriate time. The Court as a whole can affect its public perception through the decisions it hands down in the next four years. This Term, for example, the Court has already struck down the application of the Americans with Disabilities Act to state 
employers. ${ }^{153}$ Ironically, the ADA was one of former President George Bush's proudest achievements, and he even joined in an amicus brief asking the Court not to decide as it ultimately did. ${ }^{154}$ The Court, however, has embarked on a strong states' rights path (pace Bush v. Gore itself) and one suspects that this is not the last civil rights statute it will strike down in the name of the inherent dignity and sovereignty of the states. ${ }^{155}$

Much of the Court's recent work in the federalism area has traveled below the radar screen of public concern. Even the invalidation of the Violence Against Women Act in United States v. Morrison received barely a peep in the 2000 election. If the five-person conservative majority gets more adventurous and begins hacking away at established civil rights laws, however, more Americans may sit up and take notice. ${ }^{156}$ One suspects that the Justices will not be so crazy as to void longstanding laws prohibiting race and sex discrimination. ${ }^{157}$ But, as I noted previously, I have often been wrong before in predicting the extent of the current Supreme Court's follie à cinq with federalism. Thus, if the Court continues its path of bitterly

153. Bd. of Trs. of the Univ. of Ala. v. Garrett, 121 S. Ct. 955 (2001).

154. See David G. Savage, Court Shields States from Law Aiding Disabled; Judiciary: Justices, in a 5-4 Ruling, Back the Doctrine of States' Rights. They Say That an Employee Who Is a Victim of Discrimination Cannot Sue for Damages, L.A. TimeS, Feb. 22, 2001, at A11.

155. See Alden v. Maine, 527 U.S. 706 (1999) (holding that allowing money judgments against unconsenting states would impugn their dignity as independent sovereigns).

156. Conceivably, provisions of the Family and Medical Leave Act (FMLA), 29 U.S.C.S. $\S 2601$ (Law Co-op. 1998), might run afoul of the doctrines in United States v. Morrison, 529 U.S. 598 (2000), and United States v. Lopez, 514 U.S. 549 (1995). However much it might please ideological purists, striking down the FMLA would presumably get the attention of a large segment of the American middle class. In the alternative, the Court might simply hold the Act inapplicable to state governments under the logic of the Court's Eleventh Amendment cases. See Kazmier v. Widmann, 225 F.3d 519 (5th Cir. 2000) (holding that an employee could not sue a state for violations of the FMLA in federal court).

157. In theory, given the logic of Kimel and Garrett, the rule of Griggs v. Duke Power Co., 401 U.S. 424 (1971), might be invalid as applied to state employers. According to Griggs, Title VII of the Civil Rights Act of 1964 prohibits many business practices that have a disproportionate racial impact even without a showing of discriminatory intent. Id. at 432. Although a showing of intent is necessary for a violation of the Equal Protection Clause of the Fourteenth Amendment, Title VII applies to state employers courtesy of the Civil Rights Act of 1972, 20 U.S.C. $§ 1681$ (1994). In 1989, the Rehnquist Court tried to narrow the scope of Griggs in Wards Cove Packing Co. v. Atonio, 490 U.S. 642 (1989), only to be rebuffed by Congress's passage of the Civil Rights Act of 1991, Pub. L. 102-166, 105 Stat. 1071, codified at 42 U.S.C. $\$ \S 1981(a), 2000 \mathrm{e}-2$ (1994), signed into law by Bush pére. It is unlikely however, that the five conservatives would try to push matters further by holding Griggs inapplicable to state employers. Garrett itself reaffirmed that the Court would uphold prophylactic rules in race cases. See $121 \mathrm{~S}$. Ct. at 967 . A more interesting example would be the Pregnancy Discrimination Act of 1978 (PDA), Public Law 95-555, codified at 42 U.S.C. $\S 2000 \mathrm{e}(\mathrm{k})$, which prohibits public and private employers from discriminating against pregnant employees even though the Supreme Court has held that pregnancy discrimination is not sex discrimination under the Equal Protection Clause. See Geduldig v. Aiello, 417 U.S. 484 (1974). If the Court decided that there was insufficient evidence that banning pregnancy discrimination is necessary to prevent sex discrimination that is unrelated to pregnancy, it might in theory hold the PDA inapplicable to state employers. But limiting a twenty-year-old civil rights law would be seen as a much more revolutionary move than striking down the comparatively new and underutilized Violence Against Women Act. That is reason enough to think the Court would not risk it. 
divided 5-4 opinions, it may well make things more difficult for the President and, eventually, for itself. On the other hand, the Court might burnish its reputation by extending Bush v. Gore in a series of cases, thus demonstrating that, at least in hindsight, it acted to preserve an important principle of equal protection in the 2000 presidential election.

Because the Supreme Court made George W. Bush president, the Democrats can point to the Supreme Court as the symbol of what is wrong with the Bush presidency. They can also emphasize the injustice of letting the Court appoint the person who will nominate their colleagues and successors and send the Court careening even more strongly to the right. They can threaten to hold up Supreme Court appointments unless Bush names more moderate candidates, or they can simply refuse to allow him to appoint any Justices during his term of office. These are merely possible political strategies, and one cannot know a priori whether they will work or not. They might backfire. Nothing is guaranteed, and it is up to the Democrats (and George W. Bush) to play their respective hands wisely. This should not, however, be confused with "getting over it" or "business as usual." Rather, the rough and tumble of politics is the appropriate corrective for the events of December 12.

It is a fitting and hopeful sign that the American Constitution, although it does not explicitly countenance illegitimate presidents, does in fact provide a remedy for them. That the remedy is explicitly political is perhaps poetic justice. The boundary between law and politics is hardly an impregnable barrier. It is more like a cell membrane, porous, flexible, and highly permeable. The domains of constitutional law and constitutional politics are continually interpenetrating. Despite Justice Thomas's suggestions to the contrary, we only fool ourselves if we do not recognize the deeply political nature of constitutional decisionmaking. But a membrane is still a membrane no matter how thin, and no matter what sorts of fluids regularly flow across it. The Supreme Court must practice its politics differently from the ways that legislatures and political parties practice theirs. The majority in Bush v. Gore failed to live up to that obligation. It uncomfortably confused and improperly mingled the special and constrained form of politics called constitutional law with the more general and unconstrained forms of politics in partisan political struggle. Nevertheless, just as in the case of a particularly offensive form of political speech, the remedy for the sort of politics we do not like is more politics. But in this case, it is politics of the proper kind and in the proper venue, conducted through the forms and practices of the American Constitution. 